\title{
Red Beds of the Triassic Chugwater Group, Southwestern Powder River Basin, Wyoming
}

\section{U.S. GEOLOGICAL SURVEY BULLETIN 1917-E}

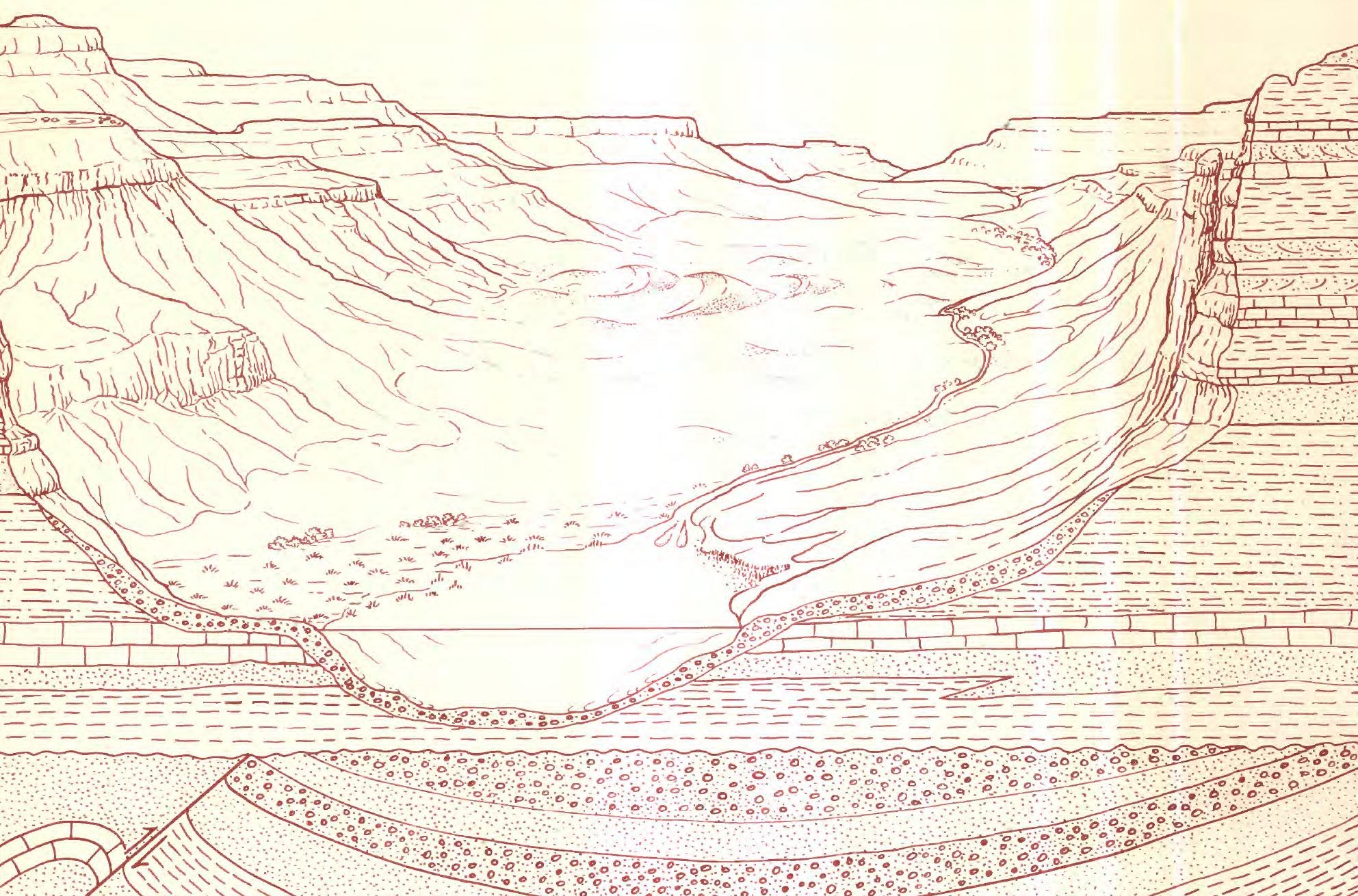




\section{AVAILABILITY OF BOOKS AND MAPS OF THE U.S. GEOLOGICAL SURVEY}

Instructions on ordering publications of the U.S. Geological Survey, along with prices of the last offerings, are given in the current-year issues of the monthly catalog "New Publications of the U.S. Geological Survey." Prices of available U.S. Geological Survey publications released prior to the current year are listed in the most recent annual "Price and Availability List." Publications that are listed in various U.S. Geological Survey catalogs (see back inside cover) but not listed in the most recent annual "Price and Availability List" are no longer available.

Prices of reports released to the open files are given in the listing "U.S. Geological Survey Open-File Reports," updated month1y, which is for sale in microfiche from the U.S. Geological Survey, Books and Open-File Reports Section, Federal Center, Box 25425, Denver, CO 80225. Reports released through the NTIS may be obtained by writing to the National Technical Information Service, U.S. Department of Commerce, Springfield, VA 22161; please include NTIS report number with inquiry.

Order U.S. Geological Survey publications by mail or over the counter from the offices given below.

\section{BY MAIL}

\section{Books}

Professional Papers, Bulletins, Water-Supply Papers, Techniques of Water-Resources Investigations, Circulars, publications of general interest (such as leaflets, pamphlets, booklets), single copies of Earthquakes \& Volcanoes, Preliminary Determination of Epicenters, and some miscellaneous reports, including some of the foregoing series that have gone out of print at the Superintendent of Documents, are obtainable by mail from

\section{U.S. Geological Survey, Books and Open-File Reports Federal Center, Box 25425 Denver, CO 80225}

Subscriptions to periodicals (Earthquikes \& Volcanoes and Preliminary Determination of Epicenters) can be obtained ONLY from the

\section{Superintendent of Documents \\ Government Printing Omce \\ Washington, D.C. 20402}

(Check or money order must be payable to Superintendent of Documents.)

\section{Maps}

For maps, address mail orders to

$$
\begin{gathered}
\text { U.S. Geological Survey, Map Distribution } \\
\text { Federal Center, Box } 25286 \\
\text { Denver, CO } 80225
\end{gathered}
$$

Residents of Alaska may order maps from

$$
\begin{gathered}
\text { Alaska Distribution Section, U.S. Geological Survey, } \\
\text { New Federal Building - Box } 12 \\
101 \text { Twelfth Ave., Falrbanks, AK } 99.701
\end{gathered}
$$

\section{OVER THE COUNTER}

\section{Books}

Books of the U.S. Geological Survey are available over the counter at the following Geological Survey Public Inquiries Offices, all of which are authorized agents of the Superintendent of Documents:

- WASHINGTON, D.C.--Main Interior Bldg., 2600 corridor, 18 th and C Sts., NW.

- DENVER, Colorado-Federal Bldg., Rm. 169, 1961 Stout St.

- LOS ANGELES, California--Federal Eldg., Rm. 7638, 300 N. Los Angeles St.

- MENLO PARK, California--Bldg. 3 (Stop 533), Rm. 3128. 345 Middlefield Rd.

- RESTON, Virginia--503 National Center, Rm. 1C402, 12201 Sunrise Valley Dr.

- SALT LAKE CITY, Utah--Federal Bldg., Rm. 8105, 125 South State St.

- SAN FRANCISCO, Callfornia--Customhouse, Rm. 504, 555 Battery St.

- SPOKANE, Washington--U.S. Courthouse, Rm. 678, West 920 Riverside Ave.

- ANCHORAGE, Alaska--Rm. 101, 4230 University Dr.

- ANCHORAGE, Alaska--Federal Bldg, Rm. E-146, 701 C St.

\section{Maps}

Maps may be purchased over the counter at the U.S. Geological Survey offices where books are sold (all addresses in above list) and at the following Geological Survey offices:

- ROLLA, Missouri--1400 Independence Rd.

- DENVER, Colorado--Map Distribution, Bldg. 810, Federal Center

- FAIRBANKS, Alaska--New Federal Bldg., 101 Twelfth Ave. 
Chapter E

\section{Red Beds of the Triassic Chugwater Group, Southwestern Powder River Basin, Wyoming}

BY V.V. CAVAROC and R.M. FLORES

A multidisciplinary approach to research studies of sedimentary rocks and their constituents and the evolution of sedimentary basins, both ancient and modern

U.S. GEOLOGICAL SURVEY BULLETIN 1917

EVOLUTION OF SEDIMENTARY BASINS-POWDER RIVER BASIN 


\title{
U.S. DEPARTMENT OF THE INTERIOR MANUEL LUJAN, JR., Secretary
}

\author{
U.S. GEOLOGICAL SURVEY \\ Dallas L. Peck, Director
}

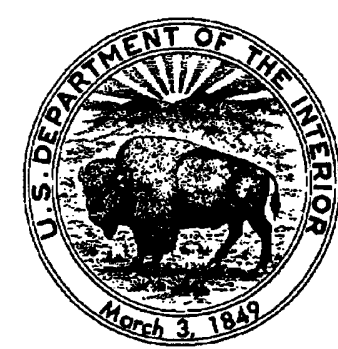

Any use of trade, product, or firm names in this publication is for descriptive purposes only and does not imply endorsement by the U.S. Government.

UNITED STATES GOVERNMENT PRINTING OFFICE: 1991

For sale by the

Books and Open-File Reports Section

U.S. Geological Survey

Federal Center

Box 25425

Denver, CO 80225

\section{Library of Congress Cataloging-in-Publication Data}

Cavaroc, Victor $\mathrm{V}$.

Red beds of the Triassic Chugwater Group, southwestern Powder River Basin, Wyoming / by V.V. Cavaroc and R.M. Flores.

p. cm. - (Evolution of sedimentary basins_Powder River Basin ; ch. E) (U.S. Geological Survey bulletin ; 1917-E)

"A multidisciplinary approach to research studies of sedimentary rocks and their constituents and the evolution of sedimentary basins, both ancient and modern."

Includes bibliographical references.

Supt. of Docs. no.: I 19.3:1917E

1. Geology, Stratigraphic-Triassic. 2. Geology-Powder River Watershed (Wyo. and Mont.) 3. Chugwater Group (Wyo.) 4. Rocks, SedimentaryWyoming. I. Flores, Romeo M. II. Title. III. Series. IV. Series: U.S. Geological Survey bulletin ; 1917-E.

QE75.B9 no. 1917-E

[QE676]

$557.3 \mathrm{~s}-\mathrm{dc} 20$ 


\title{
CONTENTS
}

\author{
Abstract E1 \\ Introduction E1 \\ Major stratigraphic units $\quad$ E2 \\ Permian E2 \\ Triassic $\quad$ E5 \\ The Red Wall valley E5 \\ Morphology E5 \\ Goose Egg Formation E5 \\ Red Peak Formation E6 \\ Lithology E6 \\ Interpretation E9 \\ Alcova Limestone E9 \\ Crow Mountain Sandstone \\ E11 \\ Unnamed red beds E11 \\ Jurassic strata E13 \\ Summary and conclusions E13 \\ References cited E15
}

FIGURES

1-2. Maps showing:

1. Mountains and basins in area of Powder River Basin, Wyoming E2

2. Areas of Early Triassic deformation and sedimentation, Utah and parts of Idaho, Nevada, Wyoming, and Montana E2

3. Chart showing Late Pennsylvanian to Middle Jurassic stratigraphy E3

4. Map and profile showing generalized geology and topography of Red Wall valley at headwaters of Middle Fork of Powder River E4

5. Stratigraphic cross section along Red Wall valley E7

6. Plane-light photomicrographs of Goose Egg and Red Peak Formations E8

7. Photographs of Red Peak Formation and Alcova Limestone E10

8. Plane-light photomicrographs of Crow Mountain Sandstone, unnamed red beds, and Sundance Formation $\mathbf{E 1 2}$

9. Photographs of Crow Mountain Sandstone, unnamed red beds, and Sundance Formation E14

10. Chart showing relationship between inferred depositional settings of Red Wall valley area and those for adjacent basins to west $\quad$ E15

TABLE

1. Microprobe and stable isotope values for selected carbonate beds E6 
. 


\title{
Red Beds of the Triassic Chugwater Group, Southwestern Powder River Basin, Wyoming
}

\author{
By V.V. Cavaroc ${ }^{1}$ and R.M. Flores ${ }^{2}$
}

\begin{abstract}
Predominantly fine-grained detrital red sedimentary rocks deposited across eastern and central Wyoming during Early to Late Triassic time interfinger with a thick sequence of Cordilleran marine rocks in western Wyoming. These red beds of the Chugwater Group are about $985 \mathrm{ft}(300 \mathrm{~m})$ thick in the study area across the southwestern margin of the Powder River Basin and are upturned along the Bighorn Mountains. They represent marginal-marine to fluvial facies that overlie Permian to Lower Triassic gypsiferous red mudstones and marine dolomites of the Goose Egg Formation along about $40 \mathrm{mi}(64$ $\mathrm{km}$ ) of very well exposed outcrops. The Chugwater in this area is truncated and unconformably overlain by the Middle and Upper Jurassic Sundance Formation.

A complex sequence of facies is represented in the Chugwater Group. The lowermost $380 \mathrm{ft}(116 \mathrm{~m})$ on the southeastern side of the Bighorn Mountains (Red Peak Formation) is an internally heterogeneous facies that coarsens upward. It consists of interbedded red mudstones, lenticular braided channel sandstones, and widespread sheets of sandstones that suggest reworked delta-front facies. The detrital beds are overlain by the light-gray, brackish-marine, algal Alcova Limestone, which is $0-11.5 \mathrm{ft}(0-3.5 \mathrm{~m})$ thick. The study area may approximate the eastern margin of a regional marine transgression associated with increased rates of shelf subsidence. The Alcova Limestone is overlain by almost $100 \mathrm{ft}$ $(30 \mathrm{~m})$ of intensely crossbedded, red sandstone (Crow Mountain Sandstone) that has properties indicating accretion of shallow-water coastal sands. Unnamed red beds of red to gray shales, red siltstones, and red to light-colored calcareous sandstones overlie the Crow Mountain. These strata represent a return to fluvial-deltaic and lacustrine environments. The uppermost unit of the Chugwater Group (Popo Agie Formation) was not observed in the study area.
\end{abstract}

\footnotetext{
Manuscript approved for publication August 30, 1990.

${ }^{1}$ Department of Marine, Earth and Atmospheric Sciences, North Carolina State University, Raleigh, North Carolina 27695.

${ }^{2}$ U.S. Geological Survey, Box 25046, MS972, Denver, Colorado 80225 .
}

Depositional environments of the Chugwater Group preserved in the study area probably represent near-shore equivalents of the shelf-dominated environments of central Wyoming.

\section{INTRODUCTION}

A major stratigraphic sequence of about $985 \mathrm{ft}(300$ $\mathrm{m}$ ) of the Triassic Chugwater Group crops out along the southwestern margin of the Powder River Basin in northeastern Wyoming (fig. 1). The uppermost $600 \mathrm{ft}(183 \mathrm{~m})$ is composed of sandy beds and forms an essentially continuous outcrop for about $40 \mathrm{mi}(60 \mathrm{~km})$. In this paper we describe the properties of these rocks and interpret their depositional environments. Geographically the rocks are between continental red beds to the east and marine red detritus of a paleoshelf to the west. These outcrops of the Chugwater are important in any regional reconstructions of Triassic sedimentation patterns in Wyoming, and the diversity of coastal environments represented in this red-bed sequence is important because red beds historically are believed to be associated with continental deposition.

Westward thickening of Triassic strata (fig. 1) in the Wyoming region reflects a gradual transition from the stable cratonic platform in the Dakotas, across the slowly subsiding cratonic margin in central Wyoming, to the rapidly subsiding Cordilleran trough near the border between Wyoming and Idaho (Carr and Paull, 1983). Shallow-water miogeosynclinal rocks extend from southwestern Wyoming into Nevada (fig. 2), and deeper water facies are present in Idaho and northern Utah (Collinson and Hasenmueller, 1978). The deformed, Early Triassic volcanic belt that trends northward across central Nevada could be a remnant of the western margin of the Early Triassic trough (Hamilton, 1978). The transition from trough sediments in Idaho to sediments of the more stable platform edge in central Wyoming was recognized and described by Kummel 


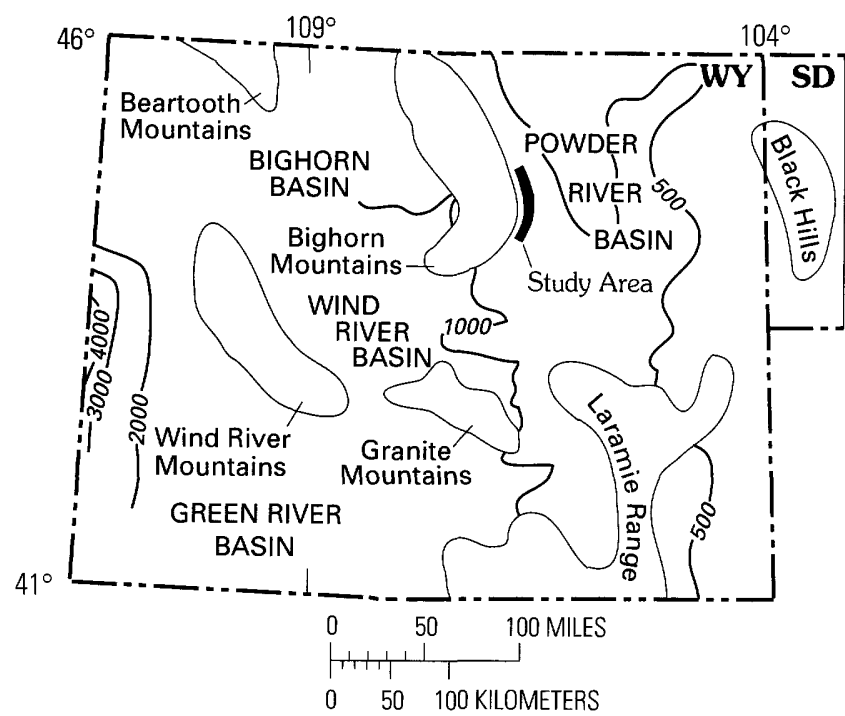

Figure 1. Mountains and basins in the area of the Powder River Basin, Wyoming. Modified from King (1977). Contour lines show the approximate thickness (in feet) of Triassic strata (McKee and others, 1967a).

(1957). Black shale and limestone characterize the deeper water environments of the basin in eastern Idaho and grade eastward into carbonate and detrital rocks of the shallowwater shelf in Wyoming. Rocks of the shelf, in turn, are intercalated with about $1,000 \mathrm{ft}(305 \mathrm{~m})$ of red beds (Chugwater Group) of the inner shelf in central Wyoming. Outcropping red beds partly of the same age in the Black Hills area of northeastern Wyoming (Spearfish Formation) are continental in origin (Downey, 1986) and pinch out to the east.

Acknowledgments.-The operators of most ranches along Middle Fork, Buffalo, and Beaver Creeks courteously provided access to their property during the 1 month of field work involved with this study. We would especially like to acknowledge the owners of the Norris Graves ranch, as well as the foreman of the Bar-C, for their assistance. Isotopic analyses of carbonate rocks were provided by Dr. William Showers at the regional stable isotope laboratory of North Carolina State University (NCSU). Microprobe analyses of rocks were also conducted at NCSU.

\section{MAJOR STRATIGRAPHIC UNITS}

\section{Permian}

Triassic strata of Wyoming record part of a depositional episode that extended from the Permian into the Early Jurassic. Rocks representing this episode are bounded by regional unconformities (Pipiringos and O'Sullivan, 1978) indicated as $\mathrm{P}-\mathrm{O}$ and J-1 on figure 3 . The Permian transgression onto the older erosion surface $(\mathrm{P}-\mathrm{O})$ is reflected on the outer paleoshelf in western Wyoming by

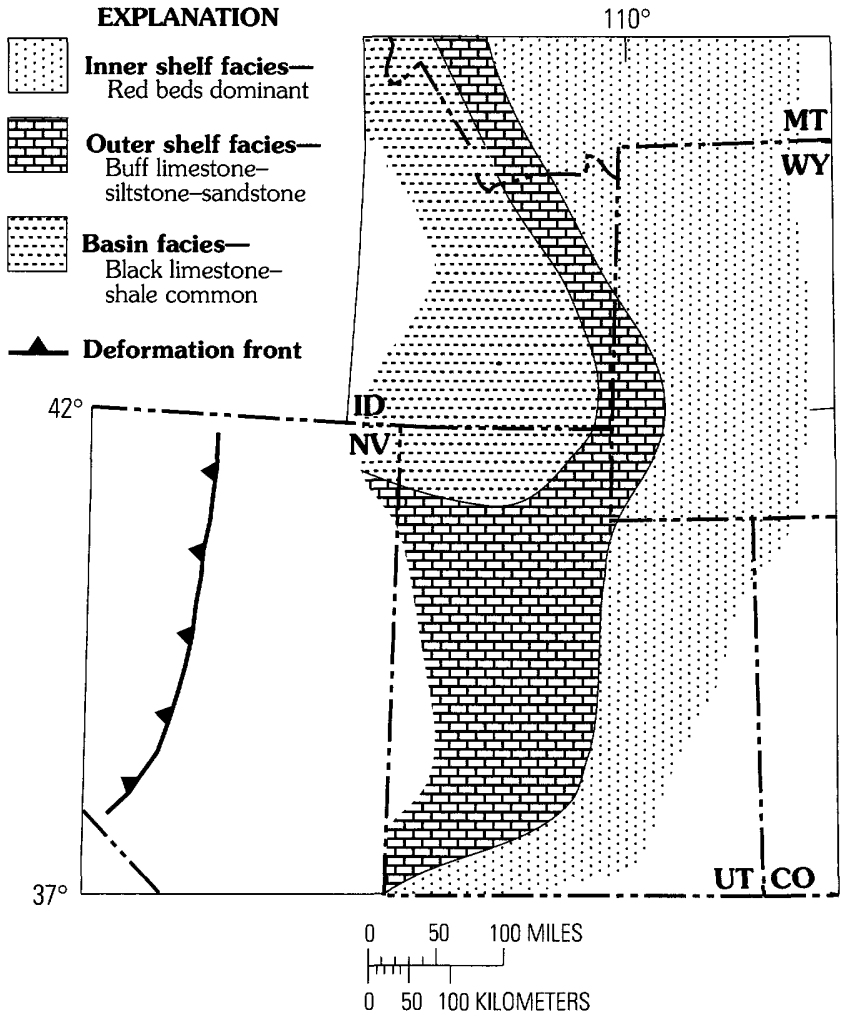

Figure 2. Areas of Early Triassic deformation and sedimentation, Utah and parts of Idaho, Nevada, Wyoming, and Montana. Modified from Kummel (1957) and Hamilton (1978).

cherty, carbonaceous, phosphatic mudstones of the Phosphoria Formation (McKee and others, 1967a). These mudstones interfinger eastward with shallow-water marine carbonate and detrital rocks of the paleoshelf in the Park City Formation. Across central and eastern Wyoming, Permian rocks consist of the widespread, red, silty mudstone of the Goose Egg Formation. These rocks contain halite and white gypsum and include purple to white dolomite and limestone beds (Love and Christiansen, 1985). Similar Permian-Triassic rocks in the Black Hills area (fig. 1) are $250-700 \mathrm{ft}(76-213 \mathrm{~m})$ thick (J.E. Fox, U.S. Geological Survey, written commun., 1986). Boyd and Maughan (1973) differentiated Permian and Lower Triassic Goose Egg equivalent strata from the Upper Permian and Lower Triassic Spearfish Formation by the greater content of thin carbonate beds in underlying strata. Pipiringos and O'Sullivan (1978) also considered the lowest part of the Spearfish to be of Late Permian age.

The Permian-Triassic boundary is well documented as an erosional surface in parts of Utah, Arizona, New Mexico, and Colorado (Pipiringos and O'Sullivan, 1978), as well as southwestern Montana (Schock and others, 1981). Throughout Wyoming, however, the boundary is either marked by a lithologic change (western region) or cannot be readily identified (eastern region). Boyd and Maughan (1973) reviewed lithologic and paleontologic data 


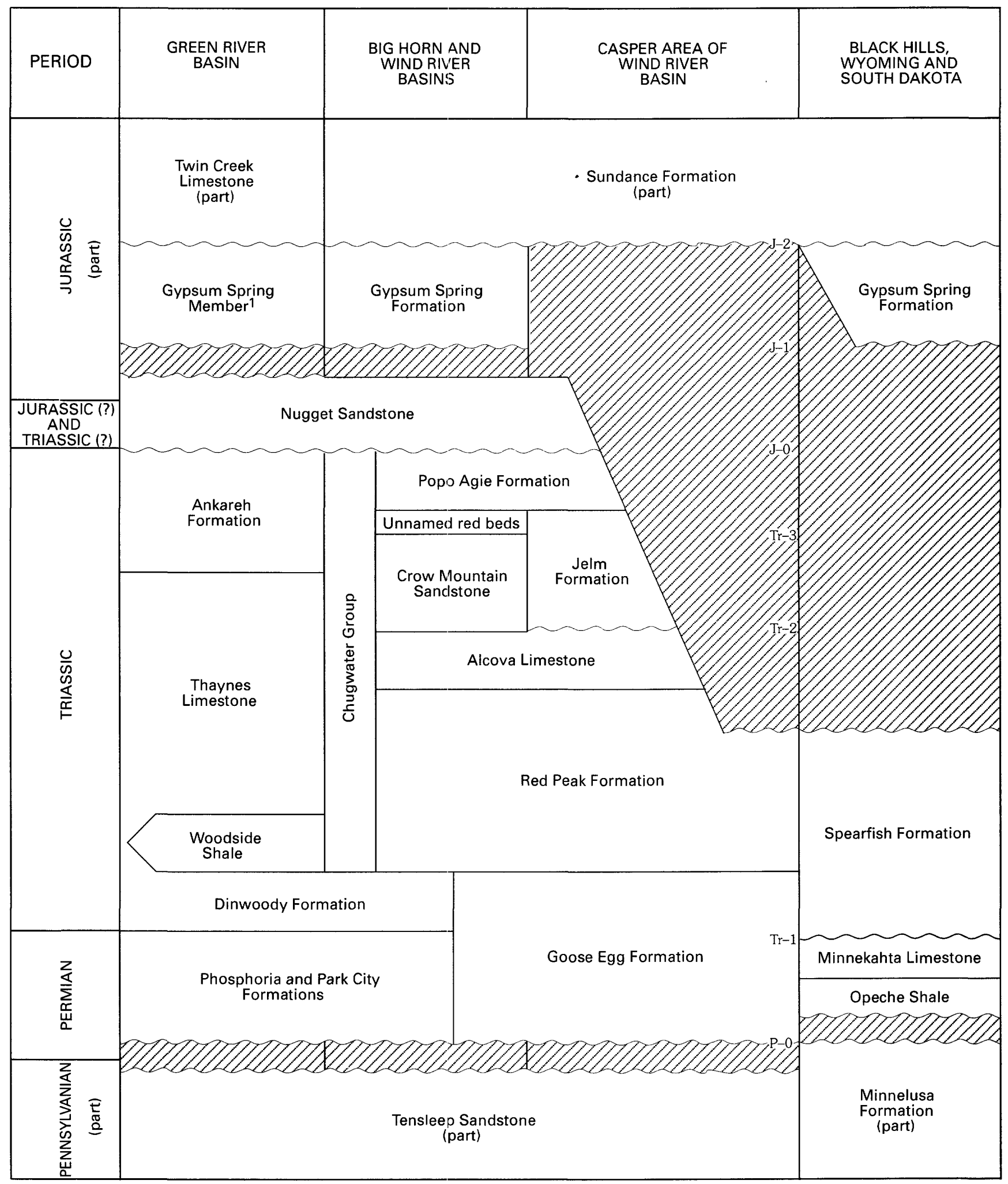

$1_{\text {Member of Twin Creek Limestone }}$

Figure 3. Late Pennsylvanian to Middle Jurassic stratigraphy, Wyoming. Stratigraphic nomenclature for Powder River Basin and adjacent areas is shown in figure 5. From Bolyard (1975), High and Picard (1967), Boyd and Maughan (1973), Pipiringos (1968), Pipiringos and O'Sullivan (1978), Picard (1978), and Keroher (1966). Reported unconformity positions (Pipiringos and O'Sullivan, 1978) are indicated by the symbols $\mathrm{Tr}-1$ through J-2; symbol P-O indicates Permian unconformity. 


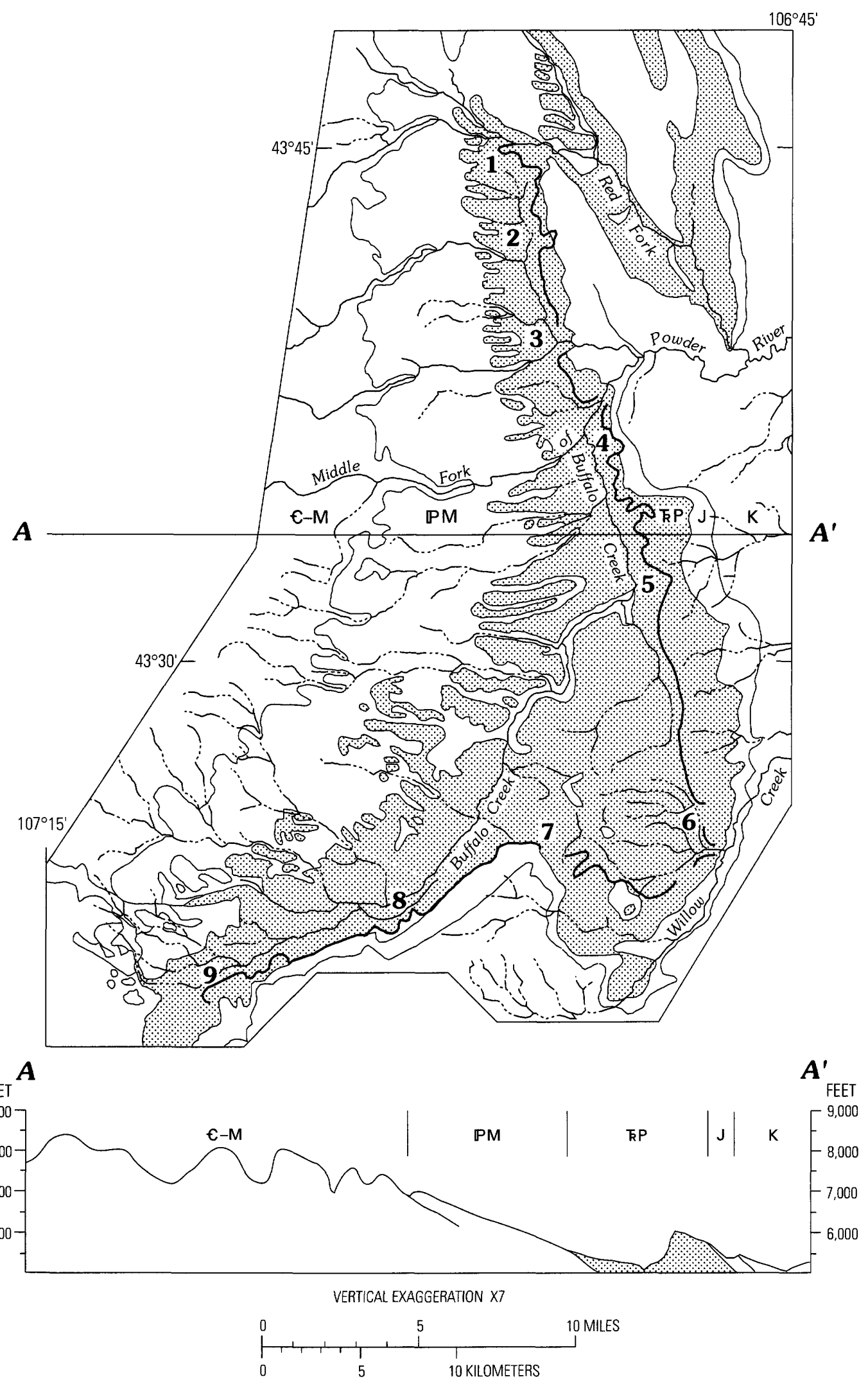


associated with the boundary and concluded that sedimentation in the western region was continuous during the latest Permian and earliest Triassic and that the boundary is marked by olive-gray, dolomitic siltstone and limestone of the Dinwoody Formation. Lithologic changes from the Permian into the Triassic across western Wyoming probably represent the beginning of a westward shift of lithologic facies that is characterized by introduction of widespread red beds (Chugwater Group) into western Wyoming.

\section{Triassic}

Picard and his co-workers described stratigraphic relationships and sedimentological facies of Triassic red beds in central and southern Wyoming in a series of papers (High and Picard, 1965, 1967; Picard, 1966, 1967, 1975a, b, 1978; Picard and High, 1968, 1972; Picard and others, 1969). High and Picard (1967) integrated their field units in the Big Horn and Wind River Basins with published stratigraphic nomenclature (for example, Love, 1939, 1957; Branson and Branson, 1941; McKee and others, 1959). In their revision of the nomenclature, the Chugwater Formation was raised to group status, and its three named members, in ascending order, the Red Peak, Crow Mountain, and Popo Agie (fig. 3), were raised to formation rank. Picard (1975a) correlated the widespread marine Alcova Limestone Member of the Crow Mountain Formation with the uppermost part of the Thaynes Limestone. Pipiringos and O'Sullivan (1978) maintained the Alcova Limestone as a formation that separates the Red Peak Formation from the younger Crow Mountain Sandstone and Jelm Formation. Picard (1978) later presented a synthesis of the lithologic types and environments of the Chugwater Group based on his earlier studies within each formation. The fine-grained detritus of the Crow Mountain and Red Peak in central Wyoming were interpreted as shallow-water shelf to tidal-current deposits, whereas the Popo Agie was interpreted as delta-plain and lacustrine deposits.

The Jelm Formation of southeastern Wyoming (Knight, 1917) is a distinctive fluvial unit of conglomeratic red sandstone. Pipiringos and O'Sullivan (1976) showed that the unit is unconformably overlain by Jurassic strata along the Laramie Range (fig. 1) and the Front Range of Colorado. The Jelm pinches out to the south in Colorado.

Figure 4 (facing page). Generalized geology and topography of the Red Wall valley at the headwaters of the Middle Fork of the Powder River. The dotted pattern shows the outcrop area of Permian and Triassic strata (Love and Christiansen, 1985). The heavy black line connects the locations of outcrop sections (sites 1-9, fig. 5) and delineates the Red Wall hogback. The two arrows designate the line of the west-east topographic profile. $€-M$, undifferentiated Cambrian through Mississippian rocks; $\mathbb{P M}$, Pennsylvanian and Mississippian rocks; $\mathbf{k} P$, Triassic and Permian rocks; J, Jurassic rocks; K, Cretaceous rocks.
Near Laramie, it overlies the Red Peak Formation and pinches out northward. Picard (1978) correlated the Jelm with light-tinted, fine-grained sandstones and micrites of deltaic origin that lie between the Crow Mountain Sandstone and Popo Agie Formation in western Wyoming.

The youngest Triassic strata in western and central Wyoming (fig. 3) are part of the Triassic (?) and Jurassic (?) Nugget Sandstone. They are unconformably overlain by younger Jurassic strata and are absent east of the Bighorn Mountains. In a regional study of Upper Triassic to Lower Jurassic sandstones that includes the equivalent Nugget, Navajo, and Aztec Sandstones, Stanley and others (1971) interpreted these rocks to be mainly of shallow marine origin in western and central Wyoming. Picard (1975b) and Knapp (1978) re-evaluated the markedly crossbedded, arkosic to subarkosic Nugget Sandstone and concluded that it is primarily an eolian deposit. Love (1957) presented evidence that suggests the lower part of the Nugget interfingers with the upper part of the underlying Popo Agie Formation, whereas High and Picard (1965) showed an unconformity between the formations.

\section{THE RED WALL VALLEY}

\section{Morphology}

During the Paleocene, Mesozoic strata were folded to form the western margin of the Powder River Basin by uplift of the Bighorn Mountains (Flores and Ethridge, 1985; Whipkey, 1988). Differential erosion by the headwaters of the Middle Fork of the Powder River along the southeastern flank of the uplift produced the northeasterly to northerly trending valley shown in figure 4 . More resistant Pennsylvanian limestones and indurated sandstones in the southern part of the Bighorn Mountains form the western margin of this valley. Less resistant red shales and mudstones of the Goose Egg Formation, which unconformably overlie Pennsylvanian strata, form most of the valley floor. The eastern side of the valley consists of almost continuous outcrops of sandy Triassic beds (upper part of the Red Peak Formation and Crow Mountain Sandstone) that form a "red wall" along the valley. This hogback, which dips about $16^{\circ}$ eastward to southeastward, is shown in figure 4 by a heavy line and is known as Red Wall. The less sandy, unnamed red beds form a sloping terrace atop the hogback and, in turn, are overlain by Jurassic (?) sandstones of the Sundance Formation that form the less continuous cliffs informally named the "gray wall." Despite excellent outcrops, Carlson (1949) has provided one of the few detailed descriptions of the strata in this area.

\section{Goose Egg Formation}

The Goose Egg Formation is poorly exposed throughout the floor of the Red Wall valley and was not 
Table 1. Microprobe and stable isotope values for selected carbonate beds

\begin{tabular}{|c|c|c|c|c|}
\hline & $\mathrm{Fe}$ & $\mathrm{Ca}$ & & $\mathrm{Mg}$ \\
\hline \multicolumn{5}{|c|}{ Alcova Limestone (algal facies) } \\
\hline Site 4 & 0.016 & 53.674 & \multicolumn{2}{|r|}{0.556} \\
\hline Site 7 & 0.008 & 53.619 & \multicolumn{2}{|r|}{0.740} \\
\hline \multicolumn{5}{|c|}{ Goose Egg Formation (dolomite bed) } \\
\hline \multirow[t]{2}{*}{ Near site 7} & 0.048 & 29.291 & \multicolumn{2}{|r|}{20.913} \\
\hline & $\delta^{13} \mathrm{C}$ & Std. dev. & $\delta^{18} \mathrm{O}$ & Std. dev. \\
\hline \multicolumn{5}{|c|}{ Sundance Formation (sandy limestone) } \\
\hline Site 4 & +0.537 & 0.006 & -9.620 & 0.020 \\
\hline \multicolumn{5}{|c|}{ Alcova Limestone (algal facies) } \\
\hline Site 4 top & -1.032 & 0.002 & -5.245 & 0.023 \\
\hline Site 4 bottom & -1.131 & 0.009 & -5.574 & 0.011 \\
\hline Site 7 & -0.877 & 0.007 & -4.842 & 0.016 \\
\hline \multicolumn{5}{|c|}{ Goose Egg Formation (dolomite bed) } \\
\hline Near site 7 & +5.055 & 0.006 & +2.210 & 0 \\
\hline
\end{tabular}

systematically investigated. It crops out best as local hills in the vicinity of site 7 and at site 1 where the valley narrows (fig. 4). Outcrops are composed dominantly of red mudstones and thin, rippled siltstones. Beds (less than $3 \mathrm{ft}$ or $1 \mathrm{~m}$ thick) of white gypsum separated by red mudstone are locally present. The gypsum beds are thinly laminated but contorted. Rarely, very thin dolomite interbeds overlie the gypsiferous interval. One such dolomite near site 7 is finely crystalline, contains indistinct outlines of marine foraminifera (fig. $6 \mathrm{~A}$ ), and has a $\mathrm{Ca}: \mathrm{Mg}$ ratio of approximately 1 (table 1). The carbon-13 isotopic value for the dolomite suggests marine deposition (Arthur and others, 1983, figs. 1-39), whereas the positive oxygen-18 values are compatible with an oxidizing, red-bed setting. Other prominent gypsiferous zones are along Buffalo Creek (about $80 \mathrm{ft}$ or $24 \mathrm{~m}$ below the base of site 5, fig. 5) and along the road following Middle Fork. Overall, the characteristics of the formation suggest accumulation in shallow, evaporitic marine waters. The lack of well-developed beds of displacement gypsum nodules discounts coastal sabkha flats as the dominant depositional setting.

The top of the Goose Egg in the Red Wall valley most likely is gradational into the overlying Red Peak Formation. At site 1, it is interpreted to lie at the top of the youngest gypsum bed. Newell (1967), however, considered the boundary to be a regional paraconformity, whereas Maughan (in McKee and others, 1967b) attributed subsurface thinning to localized tectonic uplift and erosion prior to Red Peak deposition.

\section{Red Peak Formation}

\section{Lithology}

The Red Peak Formation is dominated by red mudstone and siltstone; sandstone is common in its upper half. At site 1 (fig. 5), a complete section of the Red Peak crops out along the valley wall and is $380 \mathrm{ft}(116 \mathrm{~m})$ thick. Sheets of rippled siltstone, commonly about $3 \mathrm{ft}(1 \mathrm{~m})$ thick, are common within mudstones of the lower part of the formation (fig. 7A). The siltstones grade laterally into mudstones. Thin laminations and isolated nodules of white gypsum are commonly in the mudstones. The flaggy nature of many of the siltstone beds is caused by thin beds or laminae of silty mud. Sedimentary structures in the siltstone vary from visually massive, to wavy laminated, to almost symmetrical, vertically stacked bedforms. Somewhat thicker lenses of siltstone to very fine grained sandstone that fine upward are also present. These lenses have a scoured base overlain by well-developed, tabular ripple sets and abundant ripple-drift laminations. Small rip-clasts of mudstone have been found.

A few widespread sheets of generally fine to very fine grained sandstone as thick as $40 \mathrm{ft}(12 \mathrm{~m})$ characterize the middle and upper parts of the Red Peak Formation. These sandstone sheets dip gently within the formation in an apparent southwesterly direction (see fig. 5). The crude en echelon stacking of the sheets forms a very low angle accretionary sequence of interbedded sandstone and finer grained rocks. The sheets typically have sharp bases and rapidly grade into siltstone at their tops. The dominant bedform is current ripples. Where the sandstone is thick, subspherical weathering cavities are common on vertical outcrop faces. The updip ends of the accretionary sheets commonly are marked by high-competency current features including internal, deep (as much as $10 \mathrm{ft}$ or $3 \mathrm{~m}$ ) trough scours and sets of lateral accretion scours. Many scour surfaces are overlain by contorted rip-up clasts of laminated mudstone as long as 6 in. $(15 \mathrm{~cm})$. Small-scale sets of tabular cross-laminated sandstone (fig. $7 B$ ), commonly with ripple drift sets, typically fill the scours. The sheet sandstones are feldspathic, generally poorly sorted, and very fine to fine grained. Iron-stained grains and minor iron-stained matrix are typical (fig. $6 \mathrm{~B}$ ). The uppermost parts of the sand bodies, however, tend to contain better sorted grains in crude laminae that segregate the very fine grains from the fine and medium grains (fig. $6 \mathrm{C}$ ). The sandstone sheets laterally break up into thinner sandstone units in their downslope distal direction. Near this breakup point, the sandstone coarsens to fine grained and probably attains its best sorting and porosity (fig. 6D). These areas of increased grain size and sorting imply more prolonged reworking of the distal parts of the sheet sandstone beds.

Very thick (more than $40 \mathrm{ft}$ or $12 \mathrm{~m}$ ) lenticular sandstone bodies, as wide as $3 \mathrm{mi}(5 \mathrm{~km})$, are the other type 


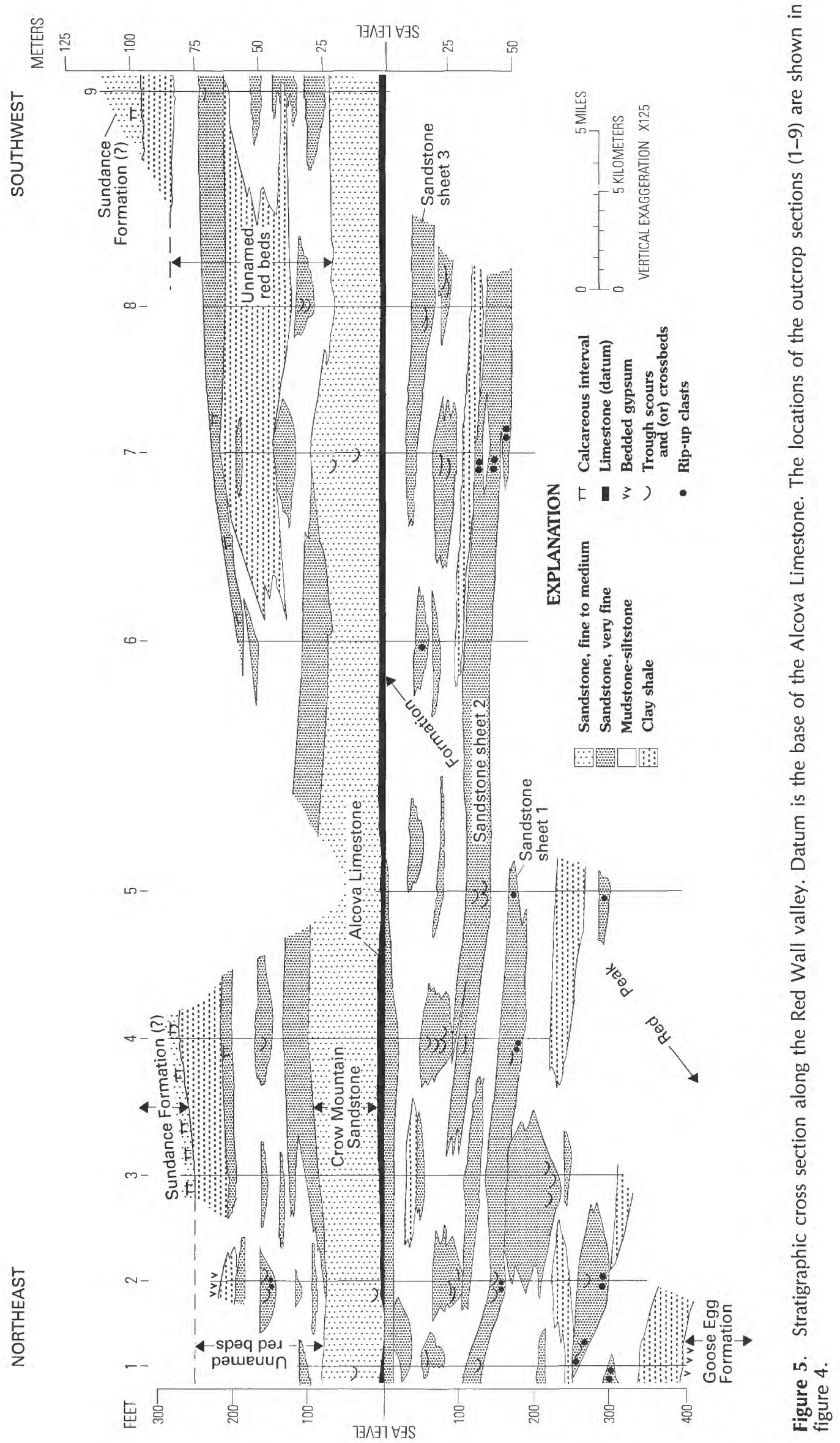



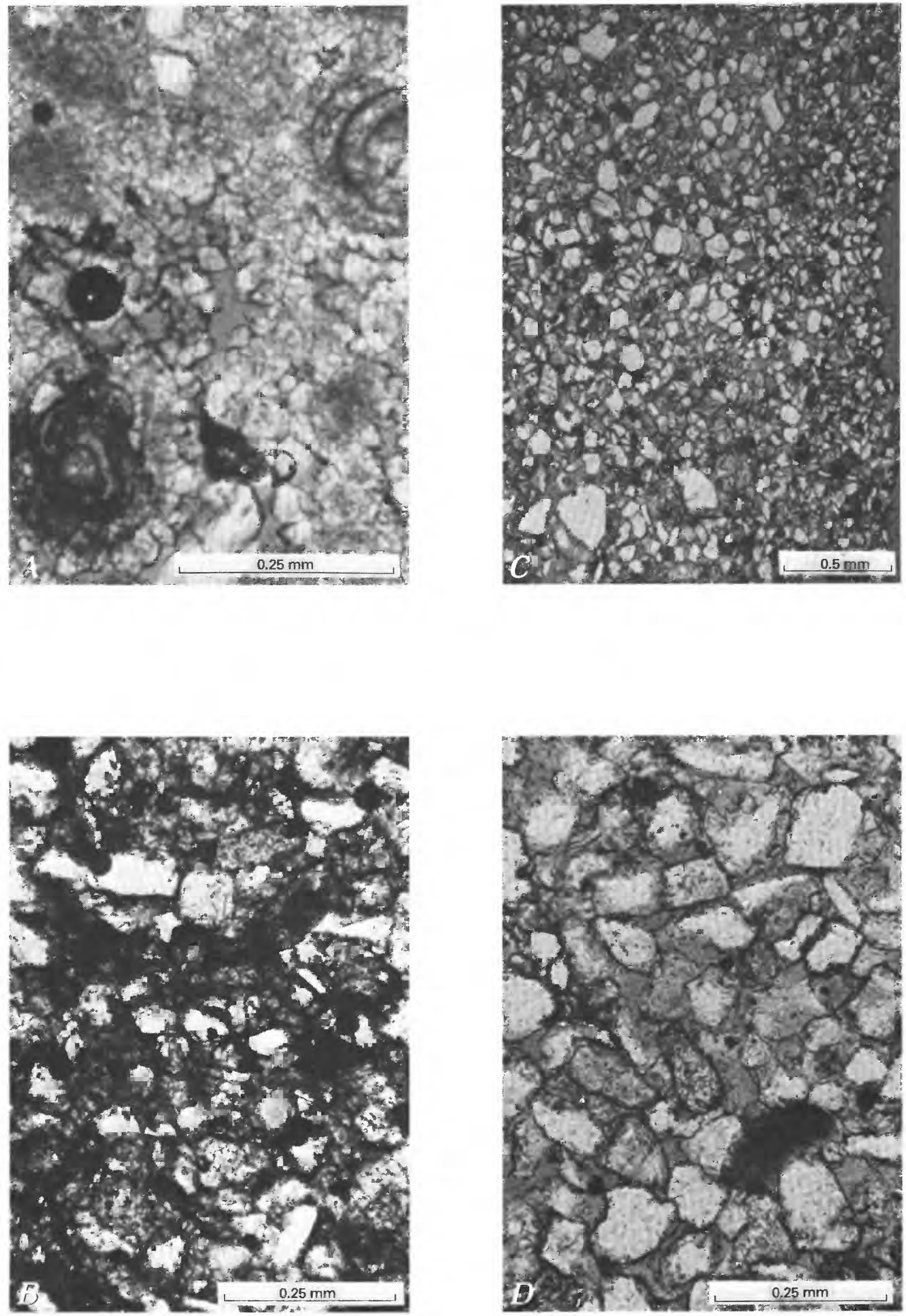
of sandstone common in the middle and upper parts of the Red Peak Formation. Visually massive and planarlaminated units, suggestive of episodes of higher flow regime conditions, are commonly interbedded with current rippled units. Internal scours and vertically repeated alternations between upper and lower flow regimes indicate episodic fluctuations in the velocity of depositing currents. The alternations are sometimes separated by thin, sandy mudstone beds.

The uppermost part of the Red Peak Formation (lower unit of the Crow Mountain as used by Picard, 1978) is a variegated, massive to turbated, silty to very fine grained sandstone as thick as $10 \mathrm{ft}(3 \mathrm{~m})$ in the Red Wall valley. The sandstone is discontinuous (fig. 5) and locally contains bioturbated areas (fig. $7 C$ ) that are suggestive of rooting by bushes or small trees. Similar mottled variegated colors and turbation are present in laterally equivalent, finer grained rocks. The mottling and rootlike turbation are evidence that the top of the Red Peak is, at least locally, a paleosol. The absence of reworked sediment between the mottled debris and the base of the overlying Alcova Limestone indicates fairly rapid subsidence and transgression in the area.

\section{Interpretation}

Descriptions and interpretations of the Red Peak Formation of the Red Wall valley are generally compatible with those for rocks in west-central Wyoming (Picard, 1978). The mudstone-dominated lower part of the Red Peak is roughly analogous to the lower two facies of Picard. It is essentially a continuation of rock types typical of the Goose Egg except for the absence of gypsum beds and the greater abundance of beds of sandy siltstone, the latter having structures suggestive of episodes of rapid sedimentation. These differences are not unexpected, given the more eastward location of the Red Wall valley. The lower mudstones probably represent a very distal subfacies of the sheet sandstone intervals; the sheet-sandstone environments probably episodically supplied an increased influx of finegrained detritus (fig. 5). Fresh water associated with these episodes may be the reason for the relative absence of gypsum in these rocks.

Figure 6 (facing page). Plane-light photomicrographs of the Goose Egg and Red Peak Formations. Site locations shown in figure 4; sheet sandstones shown in figure 5. A, Dolomite of the Goose Egg Formation contains remnants of a rotaloid benthonic foraminifera (near site 7). B, Sandstone in the central part of the proximal end of sheet sandstone 1 of the Red Peak Formation (site 3 ) shows the poor sorting and iron staining typical of the sheet sandstones. C, Sandstone near the top of sheet sandstone 1 of the Red Peak Formation (site 3) has good porosity, negligible matrix, and crudely developed laminae, all of which suggest reworking. $D$, Sandstone from the center of the distal part of sheet sandstone 2 of the Red Peak Formation is coarser grained and better sorted and has well-developed porosity as compared to $B$.
The sheet-sandstone part of the Red Peak is equivalent lithologically to Picard's (1978) alternating facies, which contain siltstone ledges traceable for more than $15 \mathrm{mi}$ $(24 \mathrm{~km})$ in the southern Big Horn Basin. Unlike the sandstone sheets of the Red Wall valley, the ledges described by Picard are made up of siltstones that are mostly massive, contain subordinate ripples, and commonly are disturbed or burrowed. The interval containing the siltstones has been interpreted as shelf or possibly tidal flat in origin. The sheet sandstones in the Red Wall valley probably represent the shallow-water accretion of reworked deltafront sandstones, possibly associated with autocyclic destructive periods. Their upslope or proximal ends exhibit high-competency scour structures and commonly interfinger into lenticular, channel-filling sandstones. The most pronounced effects of extended reworking and size winnowing are the segregation of laminae of very fine grained and fine-grained sandstone near the tops of the sheets and the removal of most of the finer size fractions in the more distal parts of the sandstone sheets. The dominance of ripples rather than larger scale, lower regime crossbedding expected in such a setting is due to the very fine grain size.

Scattered thick, lenticular channel-filling sandstones represent the fluvial systems that supplied large quantities of detritus to the delta front. These sandstone units and their associated well-developed, fine-grained (floodplain) deposits correspond to the upper platy facies of Picard (1978). The sandstones are characterized by vertical repetition of structures of the upper and lower flow regimes in cosets that commonly are separated by thin beds of sandy silt. Concave-upward scour surfaces are common within the channel sandstones. These features all suggest intermittent discharge in sandy, braided channels. The very fine grained to fine-grained sand and the obvious competency to transport much larger clasts (scour and rip clasts) imply long distances of transport. Paleosols at the top of the formation indicate subaerial exposure at the end of this cycle of detrital deposition.

\section{Alcova Limestone}

The Alcova Limestone, as thick as $11 \mathrm{ft}(3.5 \mathrm{~m})$, records an episode of marine transgression. The Red Wall valley is near the eastern limit of this widespread limestone tongue that crops out over an area of about $31,000 \mathrm{mi}^{2}$ $\left(80,000 \mathrm{~km}^{2}\right)$ in central Wyoming (Picard, 1978). The Alcova was deposited as algal mats that grade upward to closely packed and laterally linked algal stromatolite mounds as much as $2 \mathrm{ft}(60 \mathrm{~cm})$ in radius. None of the marine invertebrates, calcarenite, or pelmicrite reported from other areas was found in the Red Wall valley. The $\mathrm{Ca}: \mathrm{Mg}$ ratio of greater than 50 and the mildly negative oxygen-18 values (table 1) suggest minimal diagenetic dissolution and cementation. Relatively low carbon-13 values imply water more brackish than that of either the 

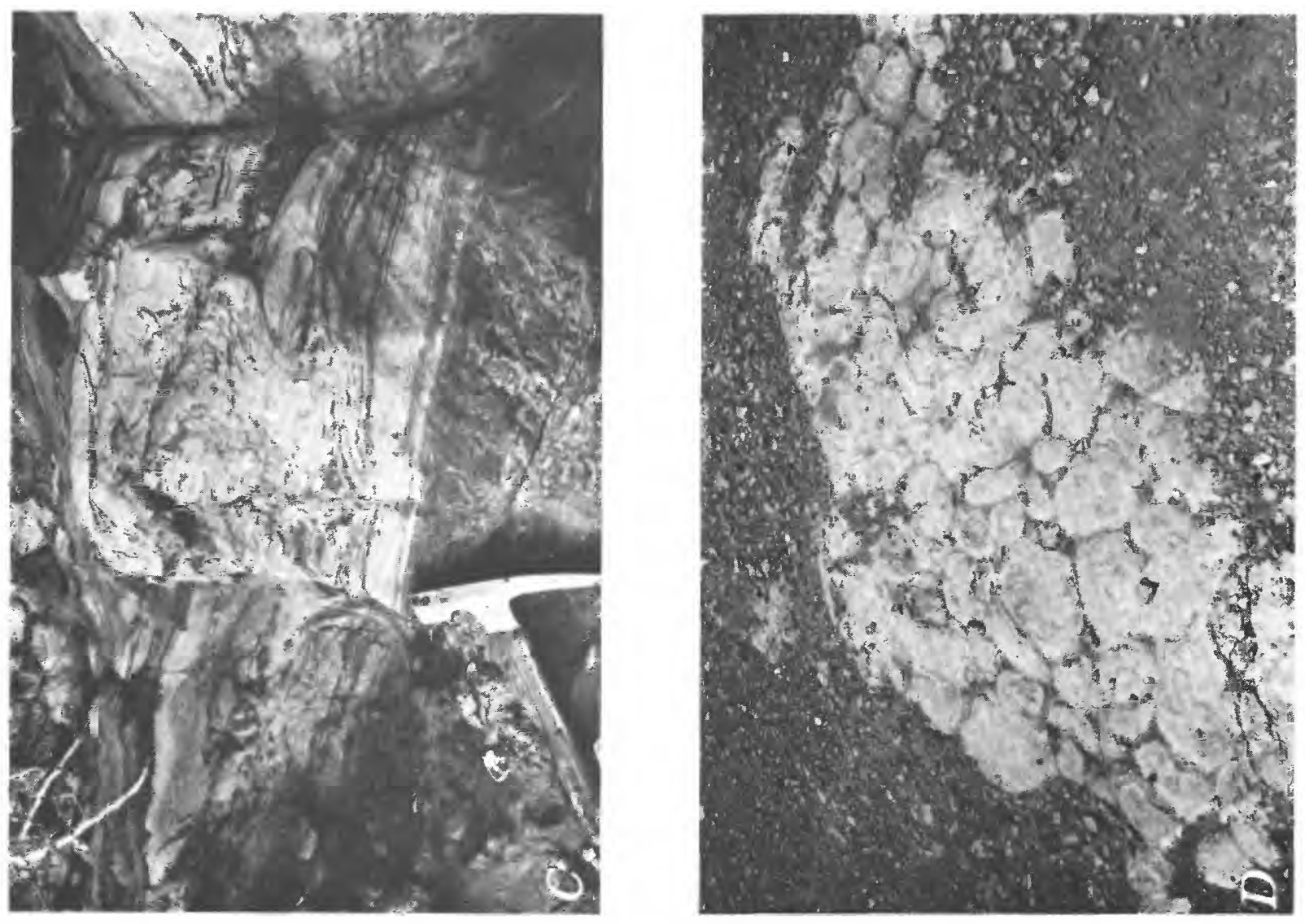

른

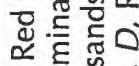

뜬잉

응 훙

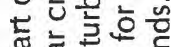

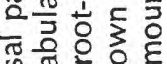

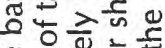
号舟

ठै

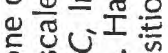

오용

紊 $\frac{\pi}{\pi} \frac{0}{\pi}$

on on

त必市

㞱芒壳

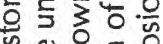

은등

这语

$<4$ 은 응

;

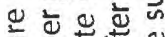

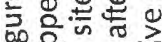

$=\frac{2}{\pi} \pi$

둘드응

든.응

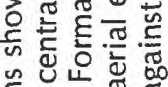

ㄴㄴㄷㄴ

을 충은

담 क
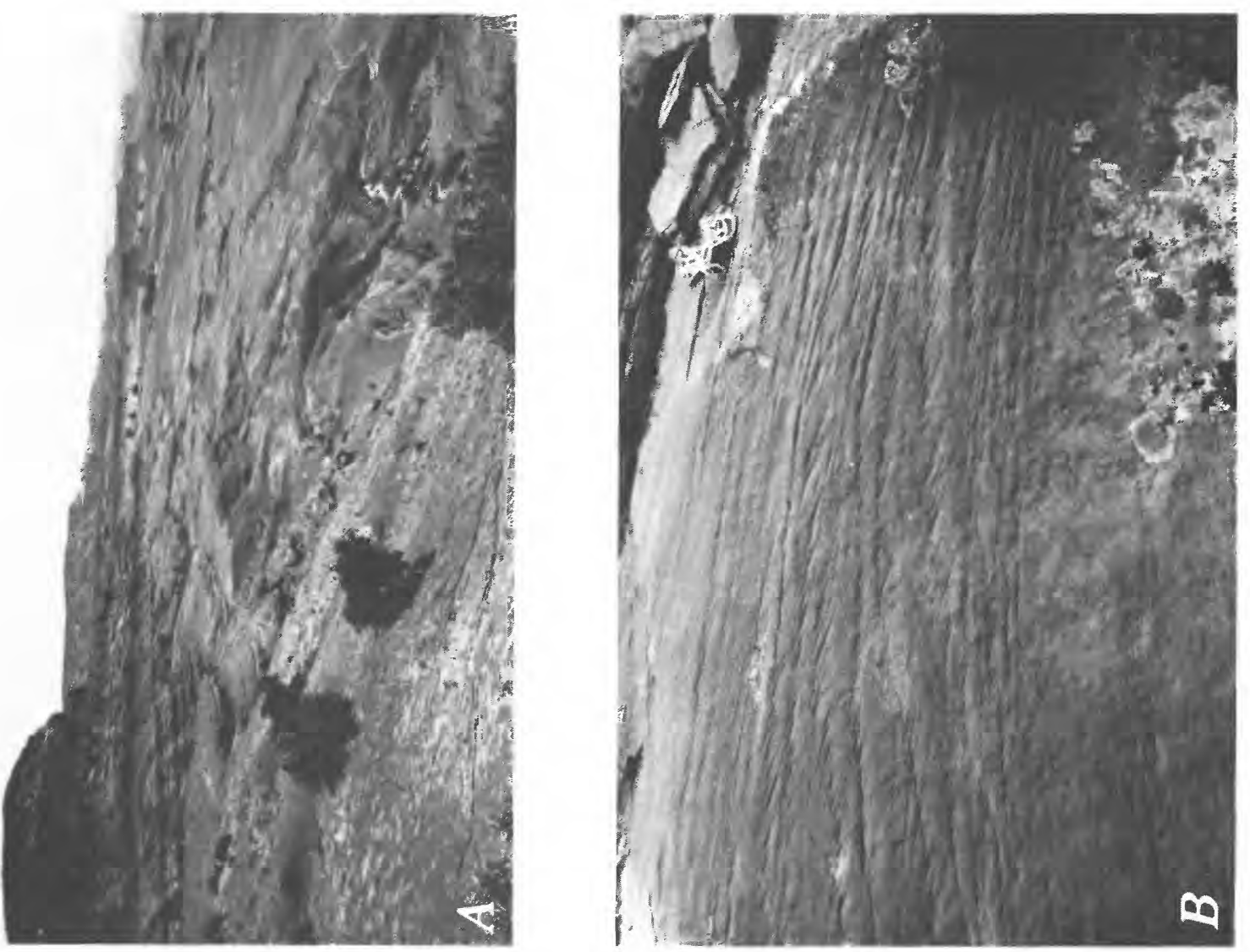

ष

क

0 0

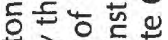

完m

Eㅍㅇㅝ

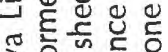

원원휴

Uัर

돈믄

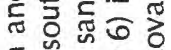

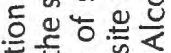

웡

토 웅ㅎㄷ

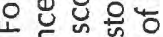

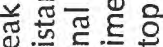

言 동

을

楼

. $.5 \frac{5}{<} \frac{8}{<}$

$\Phi$

○一

워

등. ㄷ. 든

त्रे

은요

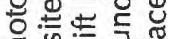

뭉ㅎㅁ

드ㅇㅝㅡㄴ

원든훙 응

产 통 है 을 
dolomite in the Goose Egg or the sandy limestone in the Sundance.

Relatively rapid subsidence resulted in carbonate accumulation directly on top of the older, partly subaerial deltaic surface. Algal mats that change upward into laterally linked mounds record deepening waters, possibly brackish because of mixing with terrestrial runoff. The environment apparently never was a suitable habitat for marine shelf invertebrates before it was inundated by well-winnowed and sorted, relatively coarse and rounded sands of the overlying Crow Mountain Sandstone. The eastern pinchout limit of the Alcova may therefore represent the actual landward extent of marine transgression in this area rather than later erosional truncation. The apparent rapidity and broad extent of the transgression that indicate widespread tectonic subsidence was superimposed on the earlier coastal-deltaic setting.

\section{Crow Mountain Sandstone}

The thick (as much as $100 \mathrm{ft}$ or $30 \mathrm{~m}$ ), predominantly light red to orange-red sandstone of the Crow Mountain Sandstone directly overlies the Alcova Limestone. This sandstone forms the upper part of the steep red walls along most of the Red Wall valley. The basal part of the sandstone locally contains scattered granules of limestone, and the basal contact may have scoured through the Alcova where it is thinnest (in the north between sites 1 and 2, figs. 4 and 5). Maughan (1972a, b) used similar small limestone clasts to define the base of the Crow Mountain in areas where the Alcova is absent; he assigned an erosional unconformity to the base of the formation. Although some scour is associated with the introduction of sand across freshly deposited algal beds, the common preservation of algal head mound relief on the top of the limestone (fig. 7D) argues against extensive subaerial erosion of the limestone in this valley prior to accumulation of the sandstone.

The main part of the red sandstone (fig. $8 A$ ) is moderately well sorted and commonly contains subrounded fine to medium sand grains. Porosity is high and the grain rims are stained by hematite. Toward the southwest, the sandstone commonly is white, sorting and roundness are less developed, grains lack hematitic rims, and carbonate cement is common (fig. $8 B$ ).

The most striking characteristic of the upper sandstone unit is the abundance and diversity of current crossbedding. This fine- to medium-grained sandstone has characteristic large-scale, lower flow regime bedforms. In general, the lowest part of the sandstone is dominated by trough crossbeds. Crudely tabular crossbed sets, some of which exhibit bimodal foreset dip directions and reactivation surfaces (fig. $9 \mathrm{~A}$ ), are common in the middle part of the sandstone. These grade upward through localized units of small trough sets into rippled flags (fig. $9 B$ ) of very fine grained to fine grained sandstone.

The Crow Mountain Sandstone represents a return of detrital influx into the area following the rapid subsidence and resulting deposition of the Alcova Limestone. The paucity of pore-filling clay in this thick sandstone interval implies a prolonged period of water turbulence sufficient to prevent clay deposition. The vertical sequence of sedimentary structures suggests that sand migrated in shallow water as the result of wave- and (or) tidal-driven current action. Initially, deposition was from discontinuous-crested dunes. Continued deposition of the sand offset subsidence, and successive tidal cycles began to rework accumulated sandbars. Equivalent units to the west (Tohill and Picard, 1966) represent more seaward facies in that they are somewhat finer grained and more calcareous and commonly show vertical, inclined, and horizontal burrows. Paleocurrent directions from crossbeds in the more seaward facies are strongly bimodal (northeast and southwest), evidence for dominance of tidal control over wave control. Tohill and Picard interpreted the more western facies as representing an upward change from shallow marine shelf to tidal flat and beach remnants. Similar shoaling is reflected in the Red Wall valley area by the transition at the top of the formation into a lower energy, very fine grained sand flat dominated by ripples (fig. 5).

\section{Unnamed Red Beds}

The unnamed red beds (probably equivalent to the Sips Creek Member of the Jelm Formation) are composed of interbedded lenticular red to pale-red to locally white sandstone, red siltstone and mudstone and intervals of gray-green clay shale. They most likely grade downward into and locally interfinger with the Crow Mountain Sandstone. The red beds form much of the gently sloping bench that separates the Red Wall from the base of the younger gray wall along the valley.

The sandstones are thick (as much as $35 \mathrm{ft}$ or $10 \mathrm{~m}$ ), lenticular, fine-grained, poorly sorted channel fills and tabular splays (generally less than $10 \mathrm{ft}$ or $3 \mathrm{~m}$ thick). The basal scoured contact of the channel fills are commonly overlain by lag rip-up clasts of siltstone. Crossbedding in the channels includes interbeds of lower flow regime large-scale trough sets and upper flow regime planar laminae. The tops of the channel-filling sandstone units mostly are gradational with overlying units and ripple dominated. Splay sands are thinner and generally can be differentiated by their very fine sand to silty grains, dominance of internal ripples, and common gradational base.

Field observations of the upper contact of the red beds are too few to clearly define the contact (fig. 5). Near the 

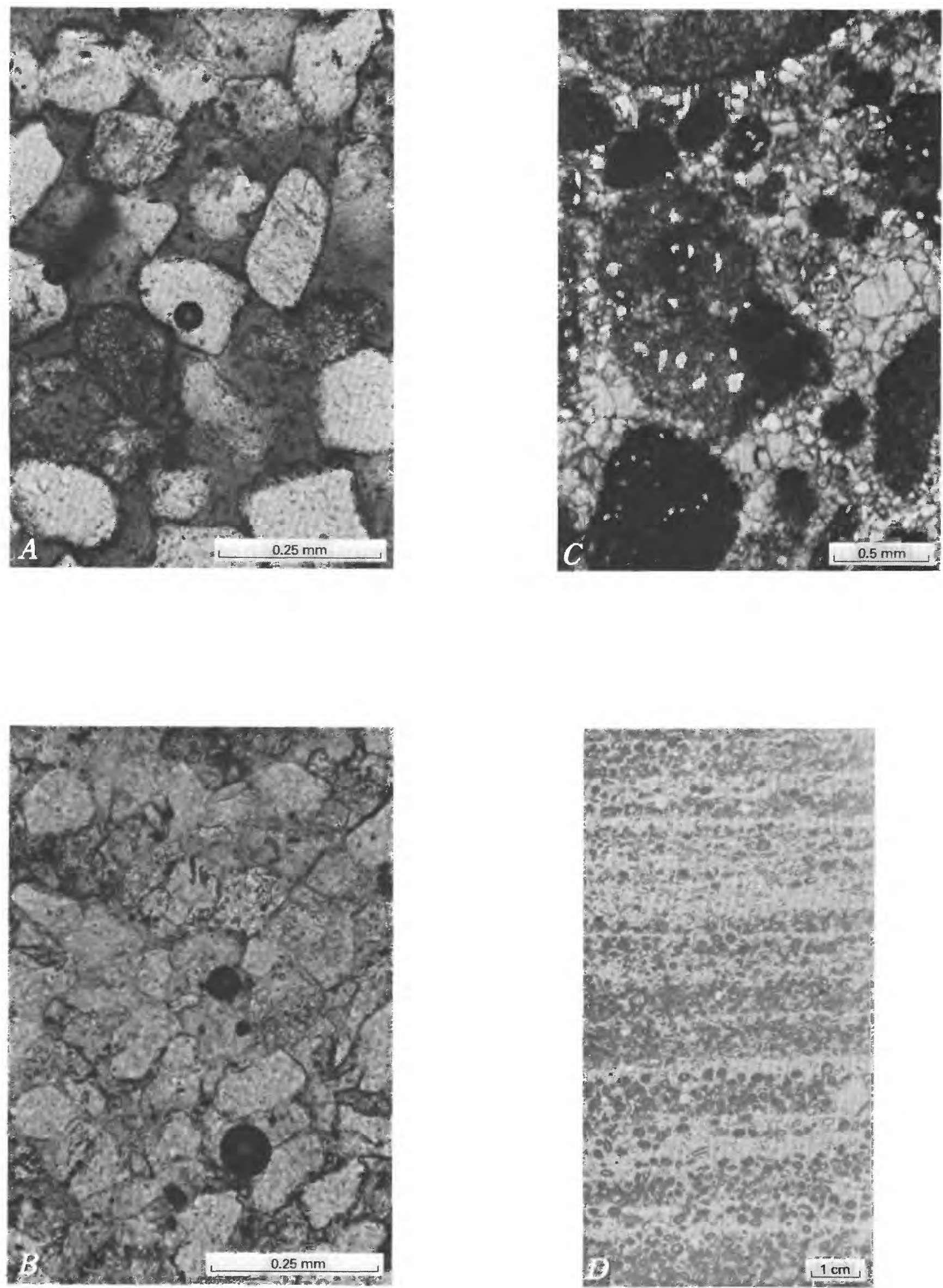
top of the red beds, however, light-yellow to white, calcareous sandstone is associated with gray-green clay shale (sites 4 and 6, fig. 5) and red mudstone. Some of the sandstone is intensely burrowed (fig. 9C). Locally, the upper part of the red beds includes sandy to silty intrasparite (fig. $8 \mathrm{C}$ ) containing intraclasts of silty micrite. Elsewhere (top of site 7, fig. 5), units of sandstone are flaser bedded. At one location (site 2), this part of the interval contains a white gypsum bed. These upper units are included with the red beds of the Red Wall valley based on the descriptions of silty micrites and light-gray-green finer detritus that are present in the Jelm of the adjacent Wind River Basin (Picard, 1978).

The characteristics of the red beds are consistent with the interpretation of Picard (1978) that equivalent strata of the Jelm Formation are part of a generally westward prograding fluvial deltaic plain. The red beds are equivalent to and probably were supplied by the high-gradient, pebbly, alluvial channel facies of the Jelm Formation in southeastern Wyoming (Knight, 1917; Pipiringos and O'Sullivan, 1976).

The calcareous sandstones, silty micrites, and red to gray-green finer detritus of the upper part of the red beds probably represent extensive lake deposits that accumulated in passive areas of a well-integrated alluvial floodplain. Large lake deposits have been described as a major component of the Popo Agie Formation (fig. 3), but the rock types of the Red Wall valley are not very similar to those described by Picard. The lower part of the Popo Agie in the Wind River Basin is a carbonate unit that is 7-33 $\mathrm{ft}(2-$ $10 \mathrm{~m}$ ) thick. The basal bed of the Popo Agie in the Wind River Basin is a limestone microconglomerate that is locally gradational with the underlying Jelm. Silty to sandy (quartz) microcrystalline limestone and dolomite also are present. Picard (1978) reported that the lower limestone is overlain by gray-red to red-brown, smectite-rich detritus of the purple unit. The dominantly lacustrine deposits of the Popo Agie (Picard and High, 1972) are characterized by fossilized reptiles, amphibians, and freshwater invertebrates.

\footnotetext{
Figure $\mathbf{8}$ (facing page). Plane-light photomicrographs of the Crow Mountain Sandstone, unnamed red beds, and Sundance Formation. Site locations shown in figure 4. A, Typically red, upper part of the Crow Mountain Sandstone (site 3) contains coarser, more rounded, and better sorted grains than the sheet sandstones of the Red Peak Formation (fig. 6B). The sandstone has open pores and iron-stained grains. B, Part of the Crow Mountain Sandstone is almost white (site 9). Grains are not iron stained and pores are filled with carbonate cement. C, Silty intrasparite sandstone from the lake (?) deposits in the unnamed red beds (top of measured section 6, fig. 5) contains intraclasts composed of silty micrite. D, Large trough crossbedded sandstone of the Sundance Formation consists of alternating laminae of quartz sand and pseudo-oolitic (oncolite?) carbonate sand. The large grain is a small chert pebble.
}

\section{Jurassic Strata}

The base of the gray wall was encountered in several of the measured sections (fig. 5). Southwestward (site 9), rocks in the lower part of the wall consist of a thick, locally calcareous, texturally submature to mature white quartz sandstone. Structures in the lower $50 \mathrm{ft}(15 \mathrm{~m})$ of the vertical cliff consist of alternating zones of platy, upper flow regime planar laminations and large-scale trough crossbeds. At the northeastern end of the valley (sites 3,4), laterally equivalent strata include white sandstone, the basal part of which contains very gently dipping, platy beds of planar laminations that underlie trough crossbed sets more than $8 \mathrm{ft}$ $(2.5 \mathrm{~m}$ ) high (fig. $9 \mathrm{D}$ ). This sandstone consists of laminae of medium- to coarse-grained, well-sorted pseudo-oolites (algal?) and medium-grained quartz sand that contains some rounded chert granules (fig. $8 D$ ). Carbon- 13 values (table 1) indicate that the sand accumulated in marine waters.

The character of the crossbeds and their oolitic nature and suggested marine affinities indicate that the gray wall is most similar to beds of oolitic sandstone to sandy oolitic limestone of the Canyon Springs Sandstone Member of the Sundance Formation. This unit crops out along the western side of the Bighorn Mountains (Imlay, 1957). It is characterized by large-scale trough crossbedding and forms a relatively continuous blanket of nearshore sand-wave deposits (Rautman, 1978) in central Wyoming (Kocurek and Dott, 1983). It was deposited during the second Jurassic marine transgression that extended eastward beyond the limits of the Nugget Sandstone (Imlay, 1957). If our interpretation is correct, the gypsum bed at the top of site 2 (figs. 4, 5) could represent a southern outlier of the Gypsum Spring Formation of the northwestern Black Hills (Mapel and Bergendahl, 1956) and north-central Wyoming (Imlay, 1957). Picard (1978), however, has reported minor amounts of gypsum within the dominantly lacustrine rocks of the Popo Agie Formation.

\section{SUMMARY AND CONCLUSIONS}

The Chugwater Group in the Red Wall valley is a complex interval of predominantly fine grained, detrital rocks that were deposited in a coastal environment. The facies represent parts of a generally westward PermianTriassic progradation of fine-grained terrigeneous detritus associated with regional subsidence of the shallow-water Cordilleran shelf. The fine grain sizes and mineralogical maturity of the sandstones suggest long transport distances. This pattern of detrital influx at rates somewhat greater than that of subsidence was interrupted only once by the abrupt eastward marine transgression recorded by the Alcova Limestone. Deposition of pebbly fluvial sandstones in southeastern Wyoming and northeastern Colorado after this transgression indicates the development of less distant source terrains for the succeeding detritus. 

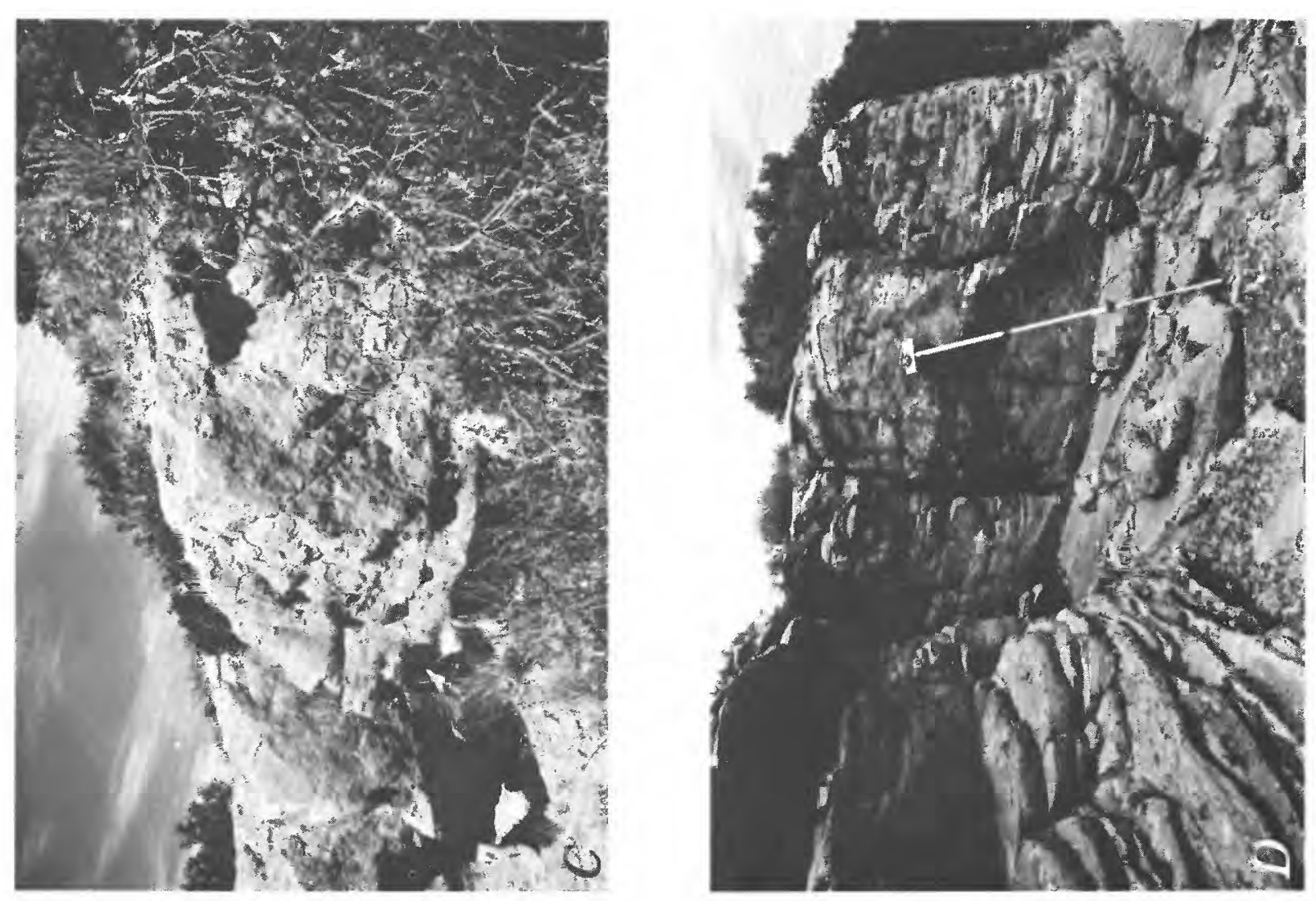

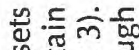

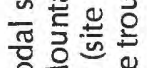
이류 흥 宁 ㄴํㄴㅇํㄴ. उ눙 I능응 중ㄴㄷㄴ 은 응동

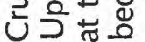
सं $\dot{\nabla} \dot{0}$ 닌 든 है 는 든. .5 옹

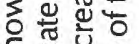
जि. 능 응 ᄃิำ तु 으 올륻 ज宅 을 文证 तٓ 0

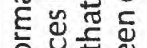
원휴 实. 뜽등 है 웅 承产吉 등 응.든
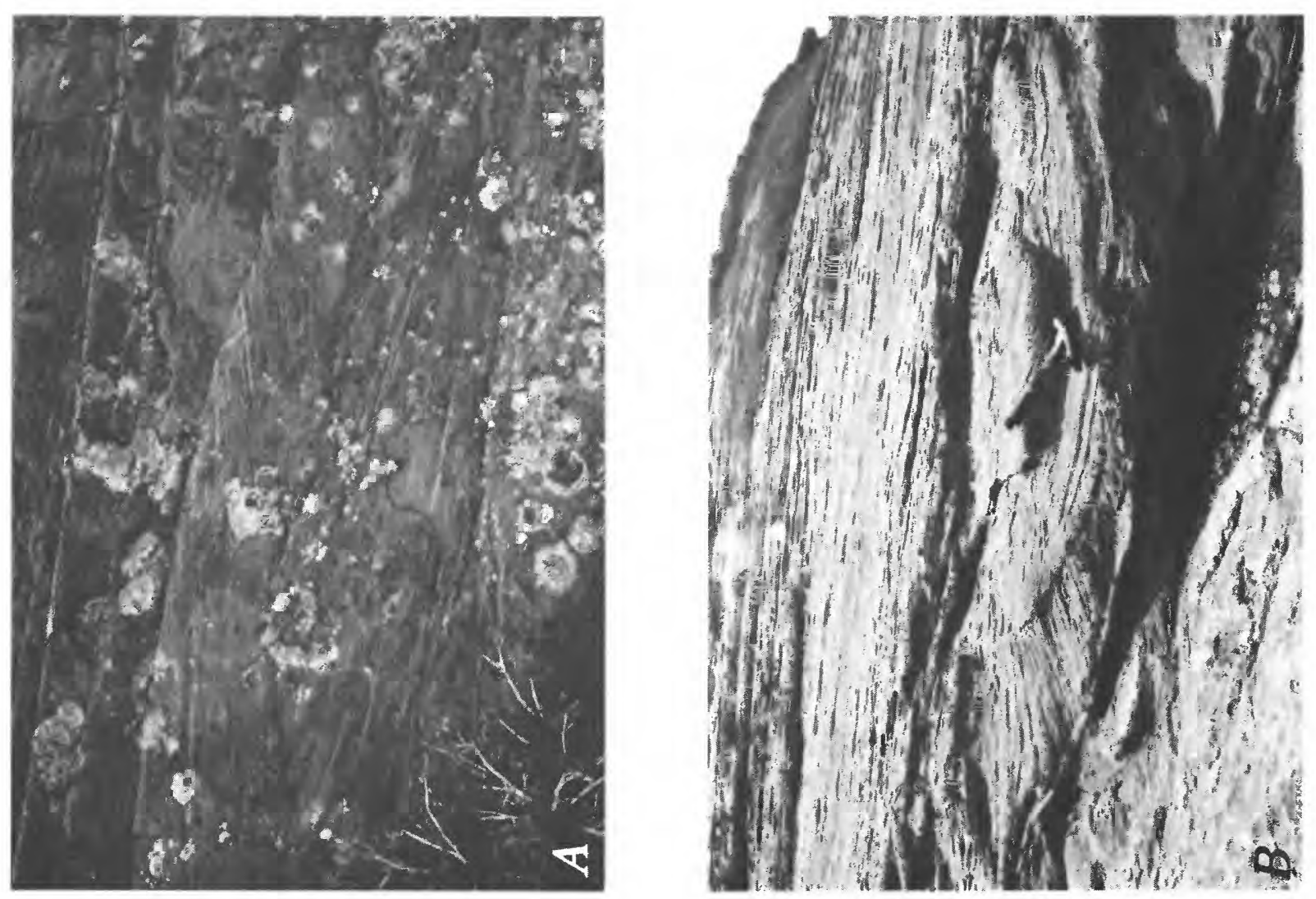
故这交 造

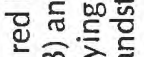
प্ है응 동요뭉 5 융 능으 我 ํํㅇ w

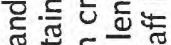
ஸึ

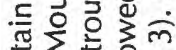

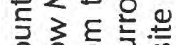
这递

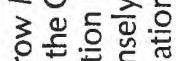
论语语

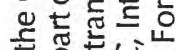
造范心 든 등 닝휴 정 कू. 융 능

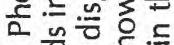
. ํํㅇㅇㅇㅎㅇ

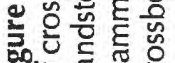

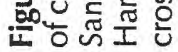


Depositional facies of formations in western and central Wyoming (Picard, 1978) are compared with the depositional facies of the rocks in the Red Wall valley in figure 10. Evaporitic marine mudstones and siltstones of the Goose Egg Formation in the Red Wall valley grade upward into shelf and distal delta mudstones and silty sandstones of the basal part of the Red Peak Formation. Reworked red delta-front sheet sandstones, characteristic of the central part of the Red Peak, separate distal delta mudstones from fluvial-deltaic red facies that supplied detritus to the system. The sheet sandstones thus probably represent approximately the shoreline position for equivalent shelf-dominated red beds to the west.

The Alcova Limestone and Crow Mountain Sand stone record a perturbation in the overall net imbalance that

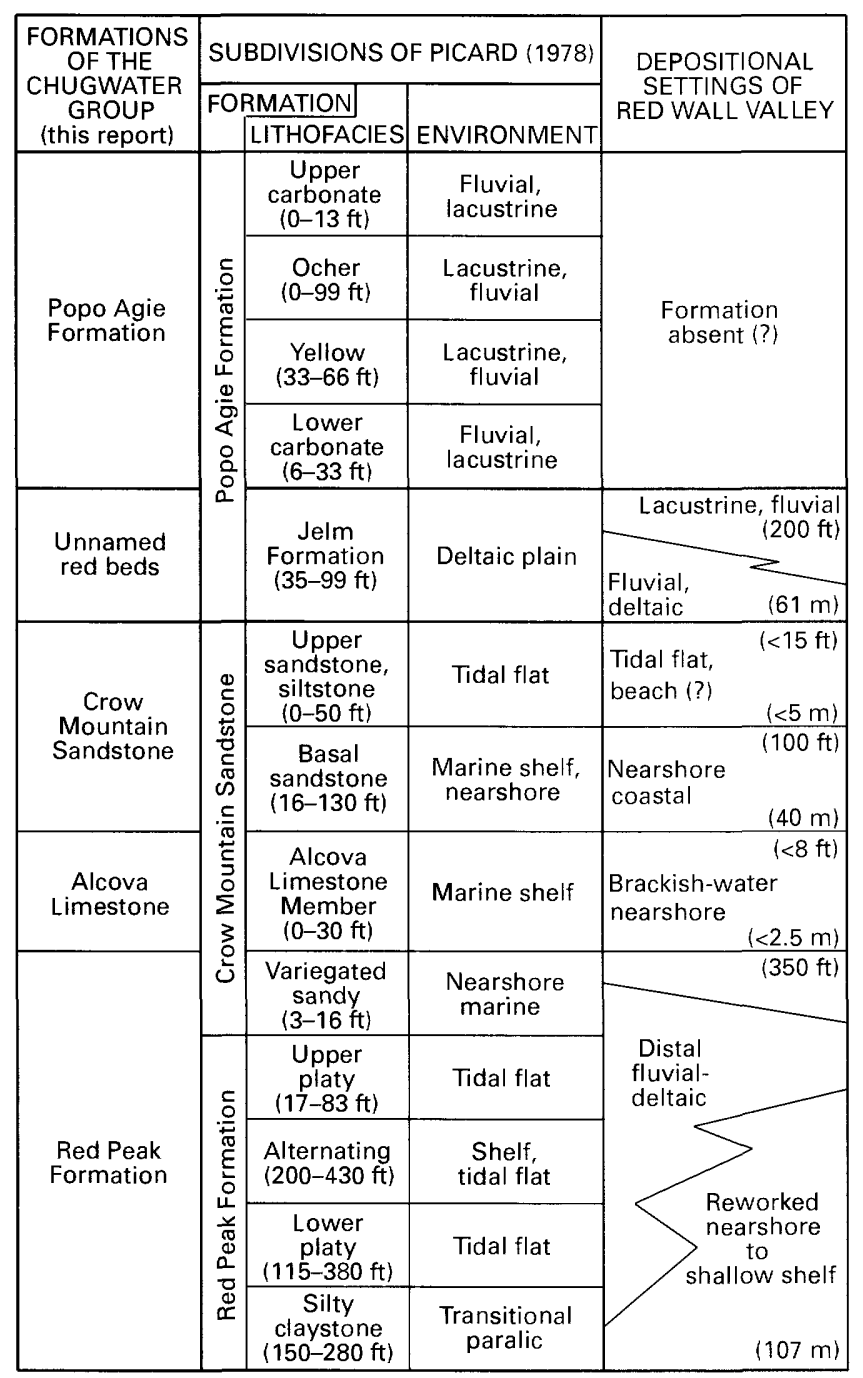

Figure 10. Relationship between inferred depositional settings of the Red Wall valley area and those reported by Picard (1978) for adjacent basins to the west. Note that the lower two units ("variegated sandy unit" and "Alcova Limestone Member") of the Crow Mountain Formation of Picard coincide with the uppermost Red Peak Formation and the Alcova Limestone, respectively, in this paper (see fig. 3). had favored terrigenous influx and progradation over shelf subsidence. Rapid transgression of marine waters resulted in deposition of the Alcova Limestone across the partly leached, subaerial sediments that form the top of the Red Peak Formation. This widespread episode of increased subsidence rate implies regional tectonic controls possibly related to compressional tectonic events along the western margin of the Cordillera. The Alcova Limestone, in turn, was buried beneath a thick, reworked Crow Mountain coastal sandstone that was introduced by some combination of wave and (or) tidal currents. The source for this coastal sand was likely the thick, pebbly alluvial sand that dominates the Jelm Formation in southeastern Wyoming (fig. 3). Deposition of very fine sand and silt as tidal (?) flats, recorded by the uppermost part of the Crow Mountain, indicates the return of active detrital progradation.

The unnamed red beds in the Red Wall valley mark the re-establishment of prograding fluvial-deltaic facies in the area. The youngest micritic units record the completion of terrigenous progradation as deposits of widespread floodplain lakes accumulated. Rocks of the Chugwater Group most likely terminate against an erosional unconformity that marks the base of the Triassic (?) and Jurassic (?) transgressive Nugget Sandstone.

The remarkable outcrops of Chugwater in the Red Wall valley of the southwestern Powder River Basin provide valuable information for regional paleoenvironmental studies in an area strategically located between carefully studied areas to the west, southeast, and east. The outcrops display an unusual group of fine-grained, generally low gradient red-bed facies that accumulated across the shoreline zone of a shallow coastal shelf.

\section{REFERENCES CITED}

Arthur, M.A., Anderson, T.F., Kaplan, I.R., Veizer, J., and Land, L.S., 1983, Stable isotopes in sedimentary geology: Society of Economic Paleontology and Mineralogy Short Course 10 , p. 5-54.

Bolyard, D.W., 1975, An overview, in Deep drilling frontiers of the Central Rocky Mountains: Rocky Mountain Association of Geologists, p. 6-7.

Boyd, D.W., and Maughan, E.K., 1973, Permian-Triassic boundary in the middle Rocky Mountains, in Logan, A., and Hills, L.V., eds., The Permian and Triassic Systems and their mutual boundary: Canadian Society of Petroleum Geologists Memoir 2, p. 294-317.

Branson, E.B., and Branson, C.C., 1941, Geology of Wind River Mountains, Wyoming: American Association of Petroleum Geologists Bulletin, v. 25, p. 120-151.

Carlson, C.E., 1949, Areal geology and stratigraphy of the Red Fork, Powder River area, Johnson County, Wyoming: Laramie, University of Wyoming, M.S. thesis, 59 p. 
Carr, T.R., and Paull, R.K., 1983, Early Triassic stratigraphy and paleogeography of the Cordilleran miogeosyncline, in Reynolds, M.W., and Dolly, E.D., eds., Mesozoic paleogeography of the west-central United States: Society of Economic Paleontologists and Mineralogists, Rocky Mountain Section, p. 39-55.

Collinson, J.W., and Hasenmueller, W.A., 1978, Early Triassic paleogeography and biostratigraphy of the Cordilleran miogeosyncline, in Reynolds, M.W., and Dolly, E.D., eds., Mesozoic paleogeography of the western United States: Society of Economic Paleontologists and Mineralogists, Pacific Section, p. 175-186.

Downey, J.S., 1986, Geohydrology of bedrock aquifers in the northern Great Plains in parts of Montana, North Dakota, South Dakota, and Wyoming: U.S. Geological Survey Professional Paper 1402-E, 18 p.

Flores, R.M., and Ethridge, F.G., 1985, Evolution of Tertiary intermontane fluvial systems of Tertiary Powder River Basin, Montana and Wyoming, in Flores, R.M., and Kaplan, S.S., eds., Cenozoic paleogeography of the west-central United States: Society of Economic Paleontologists and Mineralogists, Rocky Mountain Section, p. 107-126.

Hamilton, W., 1978, Mesozoic tectonics of the western United States, in Reynolds, M.W., and Dolly, E.D., eds., Mesozoic paleogeography of the western United States: Society of Economic Paleontologists and Mineralogists, Pacific Section, p. 33-70.

High, L.R., and Picard, M.D., 1965, Sedimentary petrology and origin of the analcime-rich Popo Agie Member, Chugwater Formation, west-central Wyoming: Journal of Sedimentary Petrology, v. 35, p. 49-70.

1967, Rock units and revised nomenclature, Chugwater Group (Triassic), western Wyoming: The Mountain Geologist, v. 4, p. 73-81.

Imlay, R.W., 1957, Paleoecology of Jurassic seas in the western interior of the United States, in Ladd, H.S., ed., Treatise on marine ecology and paleoecology: Geological Society of America Memoir 67, v. 2, p. 469-504.

Keroher, G.C., 1966, Lexicon of geologic names of the United States for 1936-1960: U.S. Geological Survey Bulletin 1200, 4 parts.

King, P.B., 1977, Evolution of North America: Princeton, N.J., University Press, $197 \mathrm{p}$.

Knapp, R.R., 1978, Depositional environments and diagenesis of the Nugget Sandstone, south-central Wyoming, northeast Utah, and northwest Colorado, in Resources of the Wind River Basin, 30th Annual Guidebook: Wyoming Geological Association, p. 131-138.

Knight, S.H., 1917, Age and origin of redbeds in southeastern Wyoming: Geological Society of America Bulletin, v. 28, p. 168-169.

Kocurek, G., and Dott, R.H., 1983, Jurassic paleogeography and paleoclimate of the central and southern Rocky Mountain region, in Reynolds, M.W., and Dolly, E.D., eds., Mesozoic paleogeography of west-central United States: Society of Economic Paleontologists and Mineralogists, Rocky Mountain Section, p. 101-116.
Kummel, B., 1957, Paleoecology of Lower Triassic Formations of southeastern Idaho and adjacent areas, in Ladd, H.S., ed., Treatise on marine ecology and paleoecology: Geological Society of America Memoir 67, v. 2, p. 437-468.

Love, J.D., 1939, Geology along the south margin of the Absaroka Range, Wyoming: Geological Society of America Special Paper 20, 134 p.

1957, Stratigraphy and correlation of Triassic rocks in central Wyoming, 12th Annual Guidebook: Wyoming Geological Association, p. 39-45.

Love, J.D., and Christiansen, A.C., 1985, Geologic map of Wyoming: U.S. Geological Survey Map G-85135, 3 sheets, scale 1:500,000.

Mapel, W.J., and Bergendahl, M.H., 1956, Gypsum Springs Formation, northwestern Black Hills, Wyoming and South Dakota: American Association of Petroleum Geologists Bulletin, v. 40, p. 84-93.

Maughan, E.K., 1972a, Geologic map of the Devils Slide quadrangle, Wyoming: U.S. Geological Survey Geologic Quadrangle Map GQ-1041, scale 1:24,000.

1972b, Geologic map of the Wedding-of-the-Waters quadrangle, Wyoming: U.S. Geological Survey Geologic Quadrangle Map GQ-1042, scale 1:24,000.

McKee, E.D., Oriel, S.S., and others, 1959, Paleotectonic maps of the Triassic System: U.S. Geological Survey Miscellaneous Geologic Investigations Map I-300, 9 plates, 33 p.

McKee, E.D., Oriel, S.S., and others, 1967a, Paleotectonic maps of the Permian System: U.S. Geological Survey Miscellaneous Geologic Investigations Map I-450, 20 plates, 164 p.

1967b, Paleotectonic investigations of the Permian System of the United States: U.S. Geological Survey Professional Paper 515, $271 \mathrm{p}$.

Newell, N.D., 1967, Paraconformities, in Teichert, C., and Yoechelson, E.L., eds., Essays in paleontology and stratigraphy (R.C. Moore Commemorative Volume): Lawrence, University of Kansas, Department of Geology Special Publication 2, p. 349-367.

Picard, M.D., 1966, Petrography of Red Peak Member, Chugwater Formation (Triassic), west-central Wyoming: Journal of Sedimentary Petrology, v. 36, p. 904-926.

1967, Stratigraphy and depositional environments of the Red Peak Member of the Chugwater Formation (Triassic), west-central Wyoming: Contributions to Geology, University of Wyoming, Laramie, v. 6, p. 39-67.

1975a, Shelf edge carbonate-redbed transitions, Red Peak and Thaynes Formations (Triassic), western Wyoming and adjacent Idaho, in Bolyard, D.W., ed., Symposium on Deep Drilling Frontiers of the Central Rocky Mountains: Rocky Mountain Association of Geologists, p. 99-107.

$1975 \mathrm{~b}$, Facies, petrography and petroleum potential of the Nuggett Sandstone (Jurassic), southwestern Wyoming and northeastern Utah, in Bolyard, D.W., ed., Symposium on Deep Drilling Frontiers of the Central Rocky Mountains: Rocky Mountain Association of Geologists, p. 109-127.

1978, Stratigraphy of Triassic rocks in west-central Wyoming, in Resources of the Wind River Basin, 30th Annual Guidebook: Wyoming Geological Association, p. 101-130.

Picard, M.D., Aadland, R., and High, L.R., Jr., 1969, Correlation and stratigraphy of Triassic Red Peak and Thaynes 
Formations, western Wyoming and adjacent Idaho: American Association of Petroleum Geologists Bulletin, v. 53, p. 2274-2289.

Picard, M.D., and High, R.L., Jr., 1968, Shallow marine currents on the early(?) Triassic Wyoming shelf: Journal of Sedimentary Petrology, v. 38, p. 411-423.

1972, Critera for recognizing lacustrine rocks, in Rigby, J.K., and Hamblin, W.K., eds., Recognition of ancient sedimentary environments: Society of Economic Paleontologists and Mineralogists Special Publication 16, p. 108-145.

Pipiringos, G.N., 1968, Correlation and nomenclature of some Triassic and Jurassic rocks in the south-central part of Wyoming: U.S. Geological Survey Professional Paper 594-D, 26 p.

Pipiringos, G.N., and O'Sullivan, R.B., 1976, Stratigraphic sections of some Triassic and Jurassic rocks from Douglas, Wyoming, to Boulder, Colorado: U.S. Geological Survey Oil and Gas Investigations Chart OC-69, 1 sheet.

1978, Principal unconformities in Triassic and Jurassic rocks, western interior United States-Preliminary survey: U.S. Geological Survey Professional Paper 1035-A, 29 p.
Rautman, C.A., 1978, Sedimentology of a Late Jurassic barrierisland complex; lower Sundance Formation of the Black Hills: American Association of Petroleum Geologists Bulletin, v. 62, p. 2275-2289.

Schock, W.A., Maughan, E.K., and Wardlaw, B.R., 1981, Permian-Triassic boundary in southwestern Montana and western Wyoming, in Tucker, T.E., ed., Field conference and symposium guidebook to southwest Montana: Montana Geological Society, p. 59-69.

Stanley, K.O., Jordan, W.M., and Dott, R.H., 1971, Early Jurassic paleogeography and sediment dispersal for the Western United States: American Association of Petroleum Geologists Bulletin, v. 55, p. 10-19.

Tohill, B., and Picard, M.D., 1966, Stratigraphy and petrology of the Crow Mountain Sandstone Member (Triassic), Chugwater Formation, northwestern Wyoming: American Association of Petroleum Geologists Bulletin, v. 50, p. 2547-2565.

Whipkey, C.E., 1988, Provenance of lower Tertiary sandstones of the Powder River Basin, Wyoming: Raleigh, North Carolina State University, M.S. thesis, 145 p. 





\section{SELECTED SERIES OF U.S. GEOLOGICAL SURVEY PUBLICATIONS}

\section{Perlodicals}

Earthquakes \& Volcanoes (issued bimonthly).

Prelimlnary Determination of Eplcenters (issued monthly).

\section{Technical Books and Reports}

Professional Papers are mainly comprehensive scientific reports of wide and lasting interest and importance to professional scientists and engineers. Included are reports on the results of resource studies and of topographic, hydrologic, and geologic investigations. They also include collections of related papers addressing different aspects of a single scientific topic.

Bulletins contain significant data and interpretations that are of lasting scientific interest but are generally more limited in scope or geographic coverage than Professional Papers. They include the results of resource studies and of geologic and topographic investigations; as well as collections of short papers related to a specific topic.

Water-Supply Papers are comprehensive reports that present significant interpretive results of hydrologic investigations of wide interest to professional geologists, hydrologists, and engineers. The series covers investigations in all phases of hydrology, including hydrogeology, availability of water, quality of water, and use of water.

Circulars present administrative information or important scientific information of wide popular interest in a format designed for distribution at no cost to the public. Information is usually of short-term interest.

Water-Resources Investigations Reports are papers of an interpretive nature made available to the public outside the formal USGS publications series. Copies are reproduced on request unlike formal USGS publications, and they are also available for public inspection at depositories indicated in USGS catalogs.

Open-File Reports include unpublished manuscript reports, maps, and other material that are made available for public consultation at depositories. They are a nonpermanent form of publication that may be cited in other publications as sources of information.

\section{Maps}

Geologic Quadrangle Maps are multicolor geologic maps on topographic bases in 71/2-or 15-minute quadrangle formats (scales mainly $1: 24,000$ or $1: 62,500$ ) showing bedrock, surficial, or engineering geology. Maps generally include brief texts; some maps include structure and columnar sections only.

Geophysical Investigations Maps are on topographic or planimetric bases at various scales; they show results of surveys using geophysical techniques, such as gravity, magnetic, seismic, or radioactivity, which reflect subsurface structures that are of economic or geologic significance. Many maps include correlations with the geology.

Miscellaneous Investigations Series Maps are on planimetric or topographic bases of regular and irregular areas at various scales; they present a wide variety of format and subject matter. The series also includes 7 1/2-minute quadrangle photogeologic maps on planimetric bases which show geology as interpreted from aerial photographs. Series also includes maps of Mars and the Moon.
Coal Investigations Maps are geologic maps on topographic or planimetric bases at various scales showing bedrock or surficial geology, stratigraphy, and structural relations in certain coal-resource areas.

Oll and Gas Investigations Charts show stratigraphic information for certain oil and gas fields and other areas having petroleum potential.

Miscellaneous Fleld Studies Maps are multicolor or black-andwhite maps on topographic or planimetric bases on quadrangle or irregular areas at various scales. Pre-1971 maps show bedrock geology in relation to specific mining or mineral-deposit problems; post-1971 maps are primarily black-and-white maps on various subjects such as environmental studies or wilderness mineral investigations.

Hydrologic Investigations Atlases are multicolored or black-andwhite maps on topographic or planimetric bases presenting a wide range of geohydrologic data of both regular and irregular areas; principal scale is $1: 24,000$ and regional studies are at $1: 250,000$ scale or smaller.

\section{Catalogs}

Permanent catalogs, as well as some others, giving comprehensive listings of U.S. Geological Survey publications are available under the conditions indicated below from the U.S. Geological Survey, Books and Open-File Reports Section, Federal Center, Box 25425, Denver, CO 80225. (See latest Price and Availability List.)

"Publlcations of the Geological Survey, 1879-1961" may be purchased by mail and over the counter in paperback book form and as a set of microfiche.

"Publications of the Geological Survey, 1962-1970" may be purchased by mail and over the counter in paperback book form and as a set of microfiche.

"Publications of the U.S. Geological Survey, 1971-1981" may be purchased by mail and over the counter in paperback book form (two volumes, publications listing and index) and as a set of microfiche.

Supplements for 1982,1983,1984, 1985, 1986, and for subsequent years since the last permanent catalog may be purchased by mail and over the counter in paperback book form.

State catalogs, "List of U.S. Geological Survey Geologic and Water-Supply Reports and Maps For (State)," may be purchased by mail and over the counter in paperback booklet form only

"Prlce and Avallabllity List of U.S. Geological Survey Publications," issued annually, is available free of charge in paperback booklet form only.

Selected copies of a monthly catalog "New Publications of the U.S. Geological Survey" available free of charge by mail or may be obtained over the counter in paperback booklet form only. Those wishing a free subscription to the monthly catalog "New Publications of the U.S. Geological Survey" should write to the U.S. Geological Survey, 582 National Center, Reston, VA 22092.

Note.--Prices of Government publications listed in older catalogs, announcements, and publications may be incorrect. Therefore, the prices charged may differ from the prices in catalogs, announcements, and publications. 


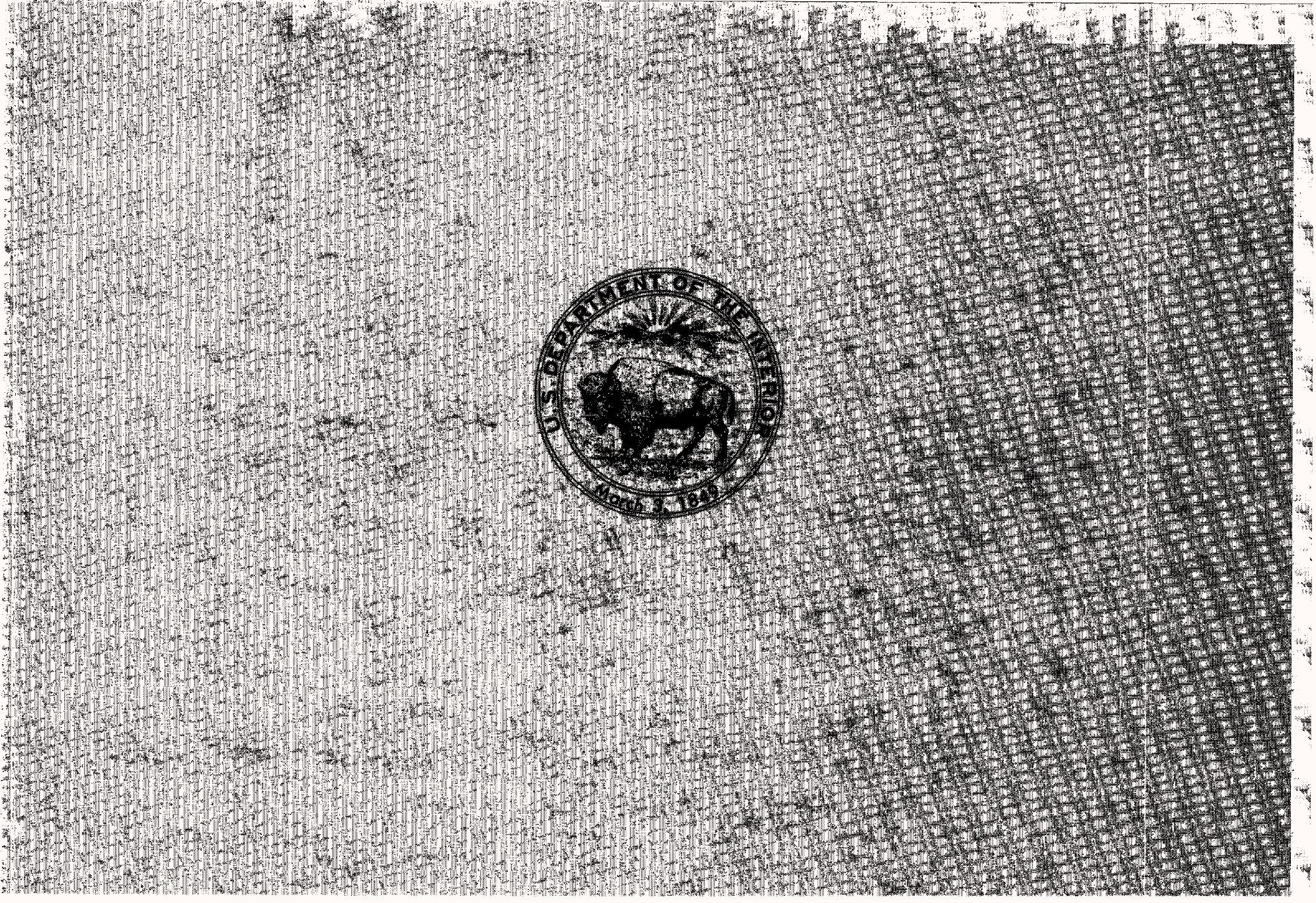

